\title{
Minimal invasive surgery of the spleen
}

\author{
ÁRON NYILAS M.D. \\ Ph.D. Thesis \\ UNIVERSITY OF SZEGED FACULTY OF MEDICINE \\ DEPARTMENT OF SURGERY \\ SUPERVISOR \\ György Lázár M.D., Ph.D., D.Sc.
}

2020

Szeged 


\section{CONTENTS}

LIST OF PAPERS 4

LIST OF ABBREVIATIONS 6

1. INTRODUCTION

2. OBJECTIVES 8

3. PATIENTS AND METHODS

3.1. Patients $\quad 8$

3.2. Surgery 9

3.3. Conception 13

3.4. Statistics 14

4. RESULTS 15

4.1. Comparison of the conventional and the minimally invasive surgical method on patients who underwent splenectomy (Study I) 15

4.1.1. Indications 15

4.1.2. Analysis of different types of surgical methods for splenectomises 16

4.1.3. Postoperative results 16

4.2. Analysis of the perioperative results of patients who underwent laparoscopic splenectomy related to spleen size, learning curve or specimen extraction method (Study II) 16

4.2.1. Indications 16

4.2.2. Surgical Procedures 17

$\begin{array}{ll}\text { 4.2.3. Postoperative results } & 18\end{array}$

4.2.4. The effects of spleen size, learning curve and specimen retrieval method 18

4.3. Study on the effect of Pfannenstiel incision in cases of extremely large spleens (Study III) 20

4.4. Analysis of the safety of splenectomy for ITP and determining which perioperative parameters predicted long-term results using evidence-based guidelines (Study IV) 21

4.4.1. Previous treatment 21

4.4.2. Results of surgery 21

4.4.3. Short- and long-term haematological results of splenectomy for ITP 21

4.4.4. Predictive factors for short- and long-term response 23

5. DISCUSSION 26

5.1. A history of splenectomy 26

5.2. Open vs. laparoscopic splenectomy (Study I) 27

5.3. The effect of the learning curve (Study II) 27

5.3. Special issue -large spleens 28

5.4. Retrieving enlarged spleens 29

5.5. Splenectomy in the treatment of ITP (Study IV) 30

5.5.1. Potential predictive factors of the efficacy of splenectomy 32

5.5.2. Reasons against splenectomy: potential complications of splenomegaly 34 
6. CONCLUSION

36

7. ACKNOWLEDGEMENTS

37

REFERENCES

38 


\section{LIST OF PAPERS}

This doctoral thesis is based on the following publications:

I. Nyilas A, Paszt A, Simonka Zs, Ábrahám Sz, Pál T, Lázár Gy. [Comparison of laparoscopic and open splenectomy] [Article in Hungarian] Magy Seb. 2013;66 : 1 pp. 14-20.

II. Nyilas A, Paszt A, Simonka Z, Abraham S, Borda B, Man E, Lazar G. Laparoscopic Splenectomy Is a Safe Method in Cases of Extremely Large Spleens. J Laparoendosc Adv Surg Tech A. 2015;25 : 3 pp. 212-216., IF: 1.297

III. Nyilas A, Paszt A, Simonka Zs, Ábraham Sz, Borda B, Mán E, Lázár Gy. [Laparoscopic removal of large spleens: Pfannenstiel incision as an alternative specimen extraction method] [Article in Hungarian] Magy Seb. 2016;69 : 1 pp. 14-19.

IV. Nyilas A, Paszt A, Borda B, Simonka Z, Abraham S, Bereczki A, Foldeak D, Lazar G. Predictive Factors for Success of Laparoscopic Splenectomy for ITP. JSLS. 2018; 22: 4 p. e2018.00021, IF: 1.654

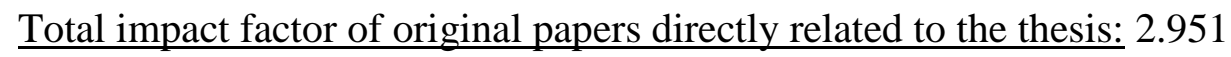

\section{List of abstracts related to the subject of the thesis}

I. Nyilas A, Borda B, Paszt A, Simonka Z, Abraham S, Lazar G: Perioperative parameters as long-term response - predicting factors for splenectomy performed for immune thrombocytopenia. $26^{\text {th }}$ International Congress of the European Association for Endoscopic Surgery, London, 2018.

II. Nyilas Á, Lázár Gy: Laparoszkópos technika alkalmazása malignus lép folyamatok esetén. A Magyar Sebész Társaság Sebészeti Onkológiai Szekciójának I. Kongresszusa, Szeged, 2017.

III. Nyilas A, Paszt A, Simonka Z, Abraham S, Borbenyi Z, Lazar G: Perioperative parameters as long-term response predicting factors in case of splenectomy performed due to ITP. XXI Annual Meeting of the European Society of Surgery, $2^{\text {nd }}$ European Meeting of Residents and PhD Students in Surgery, Krakow, 2017. 
IV. Nyilas Á, Paszt A, Simonka Zs, Ábrahám Sz, Borda B, Mán E, Lázár Gy:

Laparoscopos technika alkalmazása nagyméretü lépek eltávolítására: Pfannenstiel metszés, mint alternatív specimen eltávolítási mód. MST Sebészeti Endoszkópos Szekció XVI. Kongresszusa, Eger, 2015.

V. Nyilas Á, Lázár Gy: Laparoscopos technika alkalmazása nagyméretű lépek eltávolítására: eredményeink a lépméret, a learning curve, és a specimen eltávolítás módjának tükrében. MST 62. Kongresszusa, Győr, 2014.

VI. Nyilas A, Lazar G: Laparoscopic splenectomy. Abstr. p. 459. $21^{\text {st }}$ International Congress of the EAES, Vienna, 2013.

VII. Nyilas Á, Paszt A, Simonka Zs, Pál T, Lázár Gy: Laparoszkópos splenectomia: eredményeink az eltávolított lépek tömegének tükrében. A Magyar Sebész Társaság Sebészeti Endoszkópos Szekciójának XV. Kongresszusa, Herceghalom, 2013.

VIII. Nyilas Á, Paszt A, Simonka Zs, Ábrahám Sz, Pál T, Lázár Gy: Laparoszkópos és nyitott splenectomia klinikánkon. Magyar Sebész Társaság 61. Kongresszusa, Szeged, 2012.

IX. Nyilas Á, Paszt A, Simonka Zs, Lázár Gy: Minimálisan invazív lépsebészet. A Magyar Sebész Társaság Sebészeti Endoszkópos Szekciójának XIII. kongresszusa, Szeged, 2009.

\section{Publications not directly related to the thesis:}

I. Nyilas A, Palásthy Zs, Mihály Zs, Veres-Lakos E, Szeberin Z. [Management of extracranial carotid aneurysm] [Article in Hungarian] Orv Hetil. 2019; 160(21):815821. IF: 0.564

Cumulative impact factor: 3.515 


\section{LIST OF ABBREVIATIONS}

AS

accessory spleen

AIHA autoimmune hemolytic anemia

CR complete response

EAES European Association for Endoscopic Surgery

g $\quad \operatorname{gram}(\mathrm{s})$

HALS hand-assisted laparoscopic splenectomy

ITP idiopathic thrombocytopenic purpura

IVIG intravenous immunoglobulin

LMWH low-molecular-weight heparin

LS laparoscopic splenectomy

NHL non-Hodgkin lympoma

NR non-response

OS open splenectomy

PLT platelet

$\mathrm{R} \quad$ response

TPO-RA thrombopoietin receptor agonist 


\section{INTRODUCTION}

Since its introduction in 1991, ${ }^{1}$ laparoscopic splenectomy has been considered the gold standard in spleen surgery, and the advantages of this technique over open surgery are indisputable. Although operative times are longer for LS than OS, LS is associated with a significant reduction in splenectomy-related morbidity, primarily as a function of fewer pulmonary, wound, and infectious complications and a shorter postoperative hospital stay. ${ }^{2,3}$

Only a limited number of studies are available in Hungarian literature on patient population. ${ }^{4,5}$ The laparoscopic technique for splenectomy was initiated in the Department of Surgery, University of Szeged in 1994 and since then our working group has gained one of the greatest experience in this field in Hungary.

Although initially the usability of the laparoscopic technique was believed to be limited in cases of enlarged spleens, the safety of the method has also been shown in spleens of extreme size. ${ }^{6}$ As the laparoscopic procedure has become widely used in the case of extreme-sized spleens as well, the difficulty of retrieving specimens sometimes weighing more than 2000 grams has been encountered. The usual practice is to place the specimen in an Endobag and retrieve it through one of the port sites with morcellation. In the case of hand-assisted laparoscopic splenectomy (HALS), it is obvious to retrieve the specimen through the hand port site. Besides these procedures, the retrieval of the specimen through a Pfannenstiel incision is also known. ${ }^{7}$ Based on literature data, besides spleen size, it is the learning curve that has a crucial impact on splenectomy results. ${ }^{8,9}$

The most common indication for splenectomy is idiopathic thrombocytopenic purpura (ITP). With regard to the immunological mechanism of ITP, first-line standard therapy consists of corticosteroids and intravenous immunoglobulins. If patients do not respond to the first treatment, or if the disease responds to the treatment, but continuous therapy is required, the disorder is called refractory ITP and the administration of a second-line therapy is indicated. This treatment may consist of rituximab, TPO receptor agonists and splenectomy. Of these three treatment options, splenectomy provides the best and longest-lasting results (a response rate of approximately $80 \%$ and $60 \%$ for $5-10$ years). ${ }^{10}$

The laparoscopic approach has been an acceptable surgical method in the treatment of ITP for decades due to its numerous advantages. Haematological outcomes of this method are similar to those of conventional splenectomy. ${ }^{11,12}$

However, only limited publications are available on the long-term results of splenectomy using standardized definitions and outcome criteria. ${ }^{13,14}$ 
Furthermore, with regard to the fact that splenectomy is not effective immediately in $15-25 \%$ of cases and that relapse occurs among $1 / 3$ of patients, it is important to determine predictive factors to avoid unnecessary surgeries and to plan the therapy. Several hypothetical factors have been examined in predicting the outcome of splenectomy. Literature data are available on the predictive value of age, response to steroid therapy, perioperative platelet count and characteristics of platelet sequestration. ${ }^{15}$

\section{OBJECTIVES}

(i) Compare the short- and mid-term follow-up results on patients who underwent splenectomy with the conventional and the minimally invasive surgical method (Study I).

(ii) Analyze the perioperative results of patients who underwent laparoscopic splenectomy related to spleen size, learning curve or specimen extraction method (Study II).

(iii) Study the effect of Pfannenstiel incision in cases of extremely large spleens (Study III).

(iv) Analyze the safety of splenectomy for ITP and determine which perioperative parameters predicted long-term results using evidence-based guidelines (Study IV.).

\section{PATIENTS AND METHODS}

\subsection{Patients}

Patients who had undergone laparoscopic splenectomy or open splenectomy between 1 January 2002 and 1 January 2015 were involved in our investigation.

Study I: Between January 1, 2002 and December 1, 2011141 splenectomy were performed, 124 were scheduled and 17 were urgent surgeries. Excluding the acute and extended surgeries, 54 laparoscopic splenectomies $(n=39$ women, $n=15$ men) and 30 open splenectomies $(n=17$ women, $n=13$ men) were compared. The mean age of the patients was 40 (14-74) years in the laparoscopy group and 63 (28-79) years in the open surgery group.

Study II: Between January 1, 2002 and December 31, 2013, 70 LS procedures were performed at the Department of Surgery, University of Szeged, Hungary. The male-to-female ratio of the 70 patients was 19 to 51, and the mean age was 42.6 years (14-74). Based on the weight of the removed spleens, patients were divided into three groups: Group 1: $<350 \mathrm{~g}(\mathrm{n}=42)$, Group 2: 
350 to $1000 \mathrm{~g}(\mathrm{n}=19)$, Group 3: >1000 $\mathrm{g}(\mathrm{n}=9)$. The specimen was retrieved with morcellation through the lateral port site and the extremely large spleens were retrieved through a Pfannenstiel incision.

Study III: Between January 1, 2002 and September 30, 2014, 74 LS procedures were performed at our department. The specimen was retrieved with morcellation in a conventional manner through the lateral port site in 56 cases, whereas in 12 cases, the large spleen was retrieved through a 10-12--cm-long Pfannenstiel incision. We analyzed the effect of the Pfannenstiel incision in those 11 patients who had a specimen exceeding $1000 \mathrm{~g}$.

Study IV: From January 1, 2002, to January 1, 2015, 40 splenectomies were performed for ITP. The patients had been treated in the Hematology Department, and the surgical indication was made on the basis of the hematology specialist's report. All the patients received corticosteroid therapy before surgery, and splenectomy was performed in steroid-refractory or steroiddependent cases. Azathioprine or intravenous immunoglobulin (IVIG) therapy was administered to 10 patients before surgery, as well. The female-to-male ratio was 28:12. The mean age of the patients was $46.62 \pm 17.48$ years, ITP was diagnosed at an average age of 43 years, and the surgery was performed after an average of $25.1 \pm 5.73$ months after the diagnosis. The mean duration of the follow-up was $10.9 \pm 6.9$ years.

\subsection{Surgery}

Preoperative investigation (ultrasound, CT scan - Figure 1) is recommended for obtaining information on spleen size and volume as well as the presence of accessory splenic tissue. ${ }^{16}$ Vaccination against Streptococcus pneumoniae, Neisseria meningitidis and Haemophilus influenzae were performed in each case. The surgical interventions were performed with antibiotic protection and a close monitoring of the platelet count. The patients received prophylactic low-molecular-weight heparin (LMWH) in the peri- and postoperative period (for 30 days after discharge). 


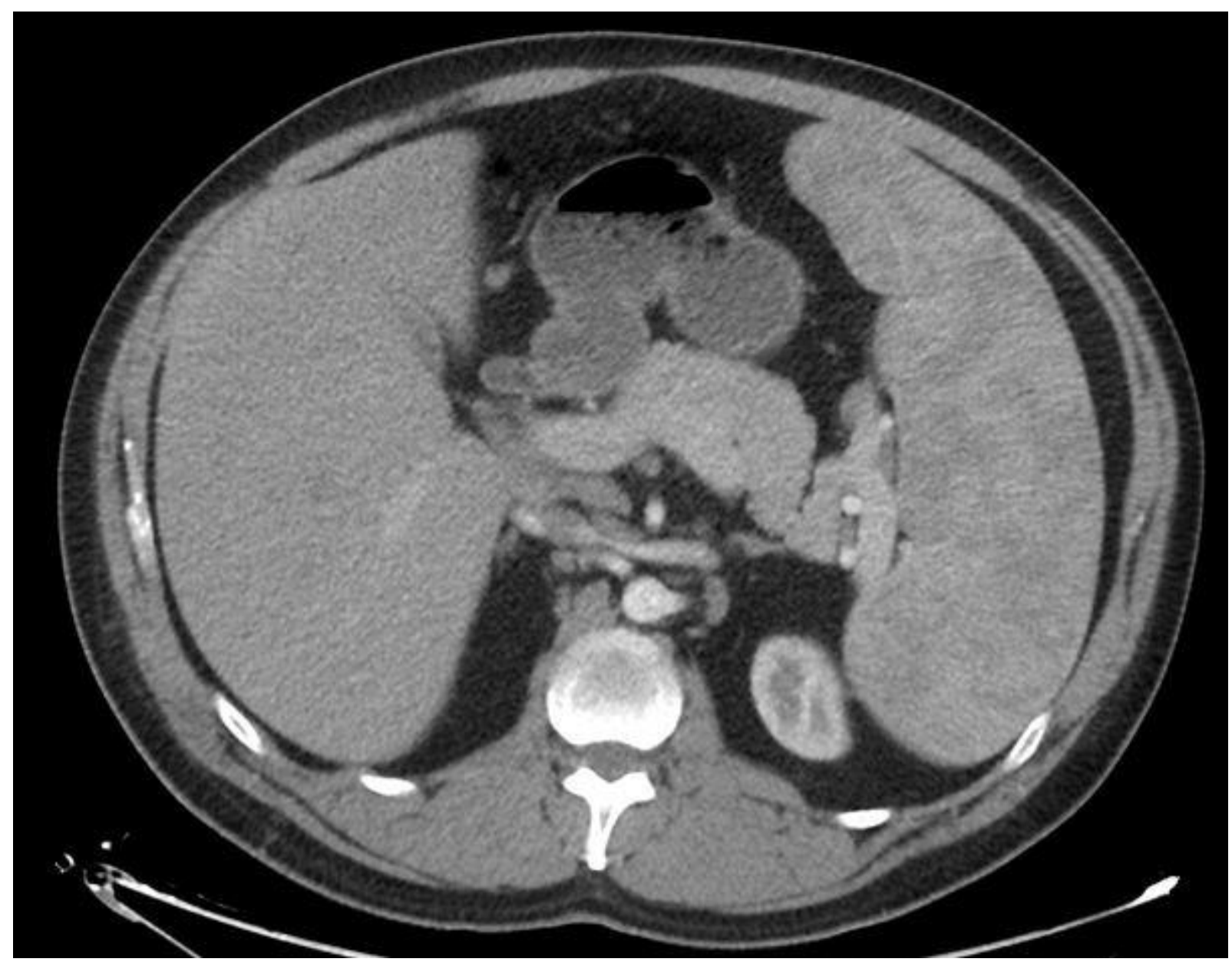

Figure 1: CT scan with splenomegaly

The laparoscopic procedures were performed in a $30^{\circ}$ lateral decubitus position with the “anterolateral, hanging spleen" technique according to Delaitre and Maignein. ${ }^{1}$ Trocars were inserted subcostally in a distance of $15 \mathrm{~cm}$. (Figure 2)

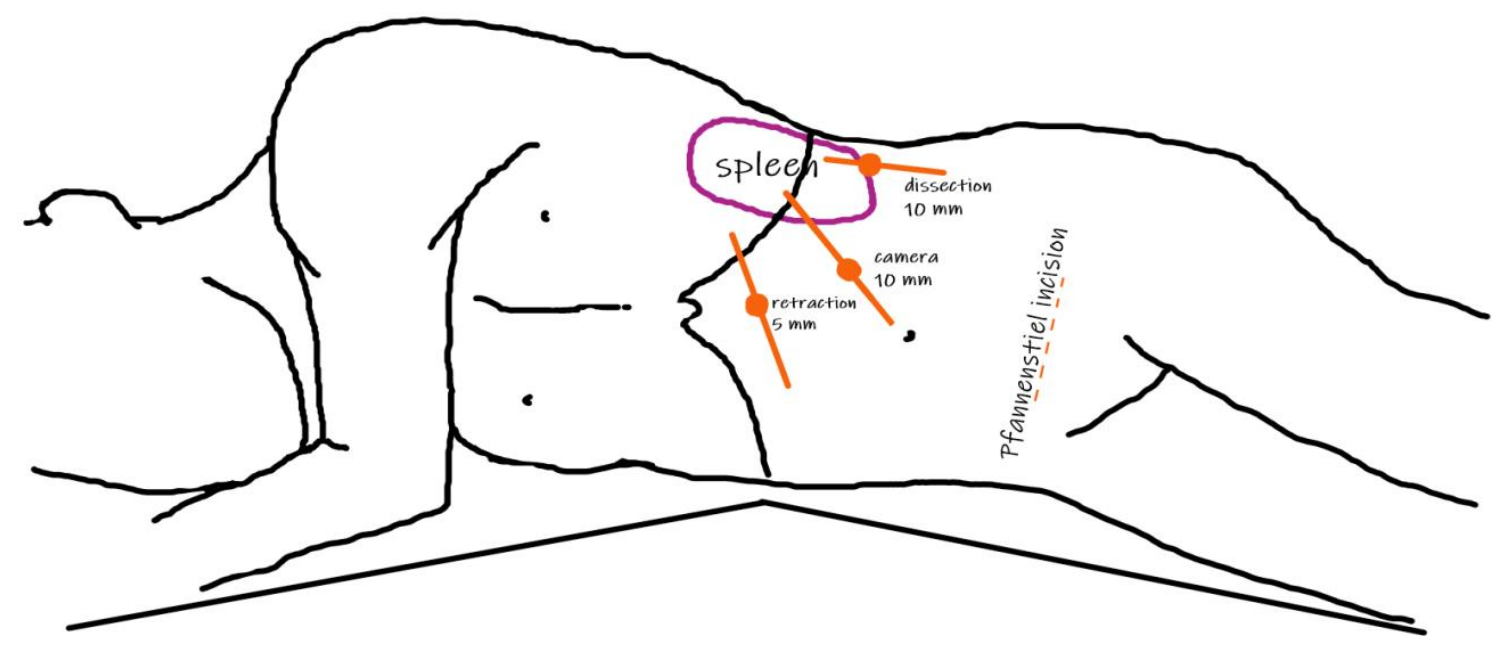

Figure 2: Patient positioning and trocar placement for laparoscopic splenectomy. 
For the control of the vessels in the splenic hilum, the Endo GIA stapler was used in the learning period until 2006, which was later replaced with individual vessel dissection and Hem-o-lok clip ligation. ${ }^{17}$ The dissection of the hilum, similarly to the method of Tan, was performed from anterior to posterior and from inferior to superior directions, which made the identification of the vessels and the pancreas easy, and with which the risk of pancreatic injury could be minimized. (Figure 3) If the patient requires platelet transfusion, it should be administered after the ligation of the splenic artery. At the end of each surgery, a drain was left in place, which was removed on the second postoperative day.

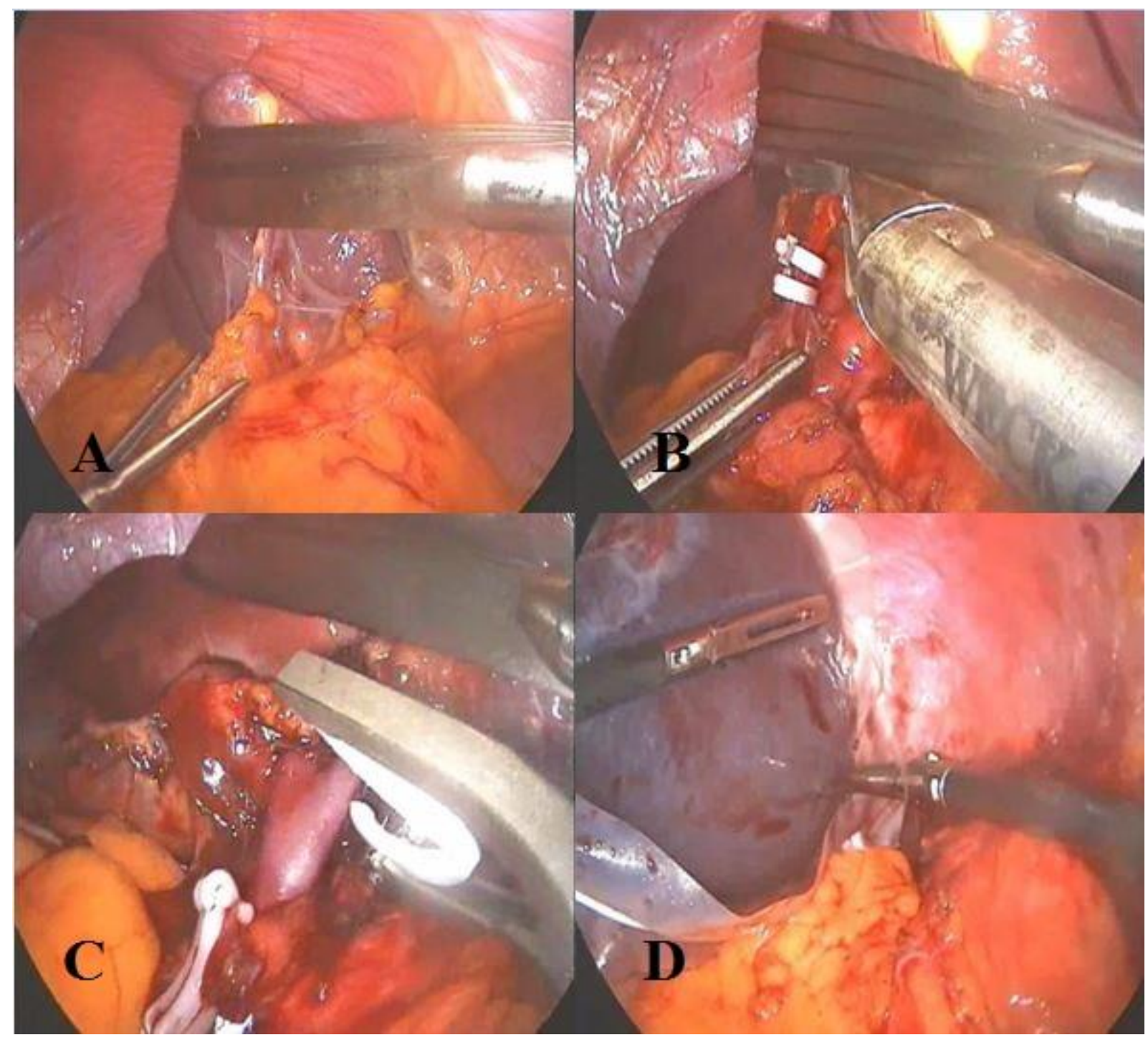

Figure 3: Steps in the LS: (A) exploration of the splenic hilum, (B) clipping of the splenic artery, $(C)$ clipping of the splenic vein, and $(D)$ removal of the specimen retrieval container

Removing the extremely enlarged spleen from the abdominal cavity is a common technical problem. The specimen is usually retrieved after placing it in an Endobag through the lateral port site with morcellation. In the case of massive splenomegaly, when the spleen weight is 
1000-2000 grams, this method is often infeasible, because the spleen size is larger than the maximum capacity of the EndoBag. According to the literature, in this case the splenic extraction was performed by specimen fragmentation in the abdominal cavity (risk of splenosis) or by a laparotomy. To solve this problem our team has been removing the specimen via a Pfannenstiel incision since 2009. (Figure 4)

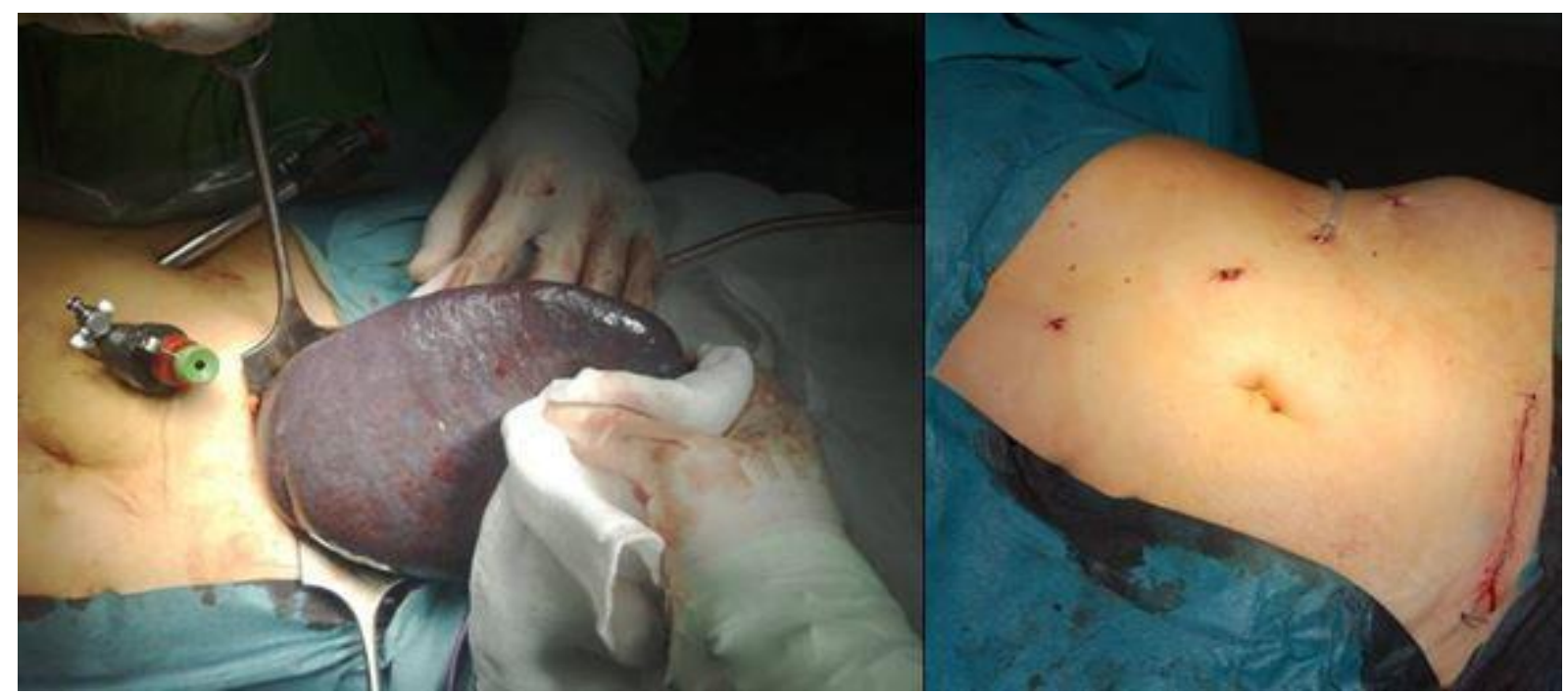

Figure 4: The Pfannenstiel incision

In cases involving the conventional method, a left subcostal laparotomy was used to perform the splenectomy. The first step was the transection of the ligamentous attachments, including the splenophrenic ligament at the superior pole and the splenocolic and splenorenal ligaments at the inferior pole. Dissection was carried out at the hilum in close proximity to the spleen to avoid injury to the pancreas. Individual ligation of the splenic artery or arterial branches and the splenic vein or venous branches is generally preferable. After removal of the spleen, hemostasis was obtained and confirmed in a systematic fashion through careful inspection of the left subphrenic area, the greater curvature of the stomach, and the short gastric vessel area as well as the splenic hilum. 


\subsection{Conception}

We evaluated the indications for surgery, the duration of surgery, the conversion rate, the reoperation rate, the time to bowel function recovery, the length of hospital stay, and the weight of the removed specimens.

In Study I the results of open and laparoscopic splenectomy were compared.

In Study II the results of the patient who underwent laparoscopic splenectomy were analyzed according to four aspects.

(i) First, the role of the learning period was investigated. The learning curve, in accordance with literature data, was defined as 20 surgeries. $^{8,9}$

(ii) The effect of using a stapler vs. clips for controlling the vessels in the hilum on our results was evaluated.

(iii) Furthermore, the role of spleen size was assessed dividing the patients into three groups based on spleen weight determined during the histological examination of the specimen: Group 1 consisted of patients with a spleen weight of less than $350 \mathrm{~g}$, Group 2 included those with a spleen weight between 350 and $1000 \mathrm{~g}$, whereas Group 3 was formed by those with a spleen weighing more than $1000 \mathrm{~g}$.

(iv.) Finally, the role of the specimen retrieval method (Endobag + morcellation vs. Pfannenstiel incision) was investigated.

In Study III the use of the Pfannenstiel incision was reviewed in the laparoscopic removal of extremely large spleens (specimen $>1000 \mathrm{~g}$ )

In Study IV ITP patients' data were analyzed in aspects of haematological response to splenectomy. In accordance with the 2009 guidelines issued by the International Working Group $^{18}$ and the evidence-based guidelines issued by the American Society of Hematology in $2011,{ }^{19}$ response was defined as platelet count over $100 \times 109 / 1$ (complete response (CR)) and at least a two-fold increase compared to the baseline value was considered to be a response (R) for a platelet count between 30 and 100 x 109/1. Non-response (NR) or lack of response was defined as the platelet count not increasing over $30 \times 109 / 1$ or not reaching a two-fold increase compared to the baseline value, or if these changes did not occur within 30 days. 
Patients were considered to be stable responders if the response was maintained during the follow-up, no additional therapy was required and there was no bleeding complication requiring hospitalization after splenectomy. The case was determined to be refractory ITP or loss of response if any thrombocytopenic event occurred with a platelet count lower than $100 \times 109 / 1$ in a previous responder patient (CR), if the platelet count was below $30 \times 109 / 1$, or if the platelet count was lower than twice the baseline value (R). Spontaneous bleeding or restarting medical therapy was regarded as a loss of response as well.

Finally, the predictive value of pre- and perioperative parameters was analysed for long-term results (CR, R, NR and loss of response).

\subsection{Statistics}

The t-test and one-way analysis of variance were used to compare the mean values, as well as the Mann-Whitney and Kruskal-Wallis tests in cases of non-normality. Categorical data were analysed by using chi-square and Fisher's exact tests. The normal distribution of samples was assessed with the Kolmogorov-Smirnov test. SPSS version 15.0 (C) 2007 SPSS Inc.) was employed for the statistical analysis. 
4. RESULTS

4.1. Comparison of the conventional and the minimally invasive surgical method on patients who underwent splenectomy (Study I)

\subsubsection{Indications}

The indications of OS and LS are represented in figure 5 and 6.

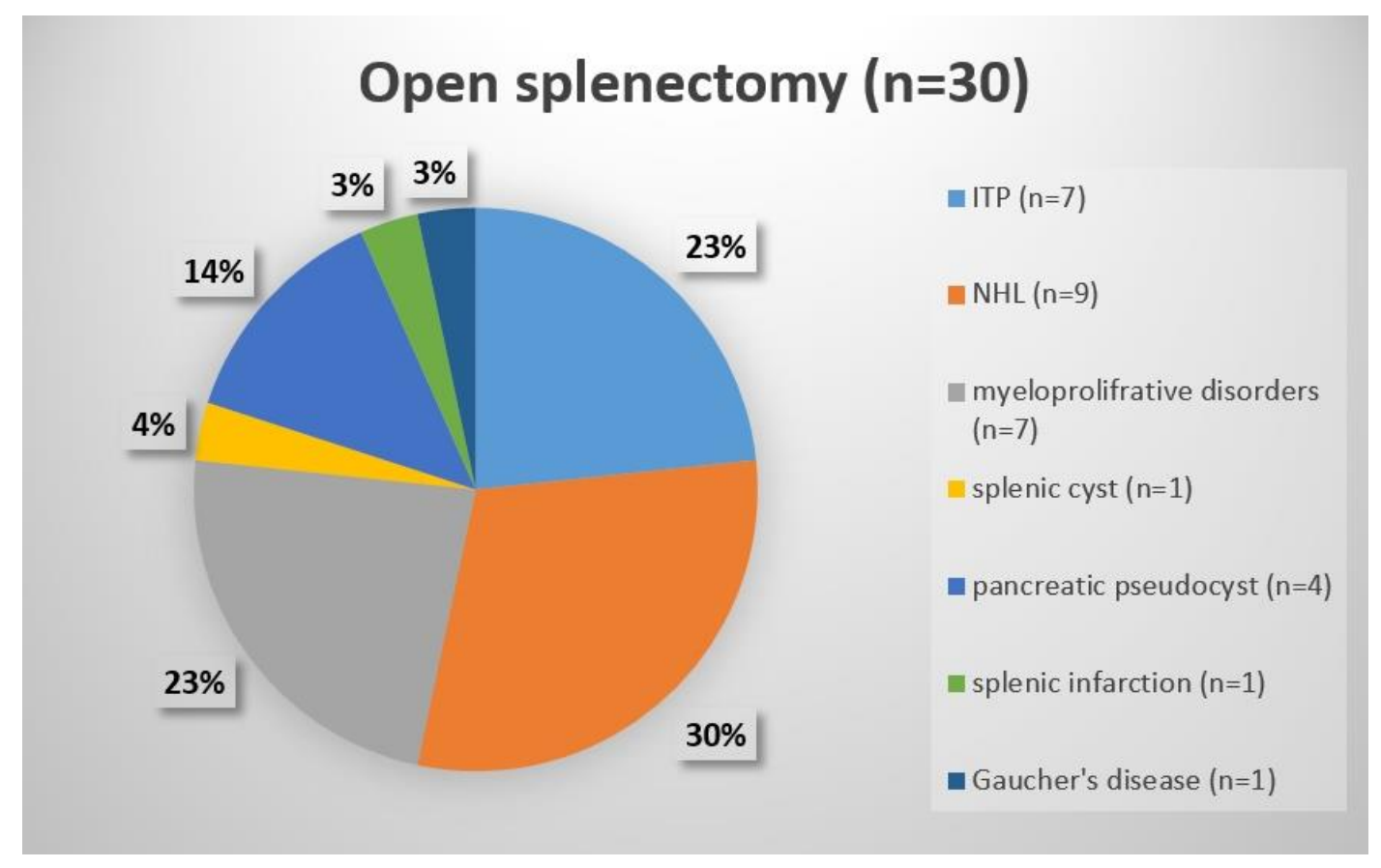

Figure 5: The indications of OS

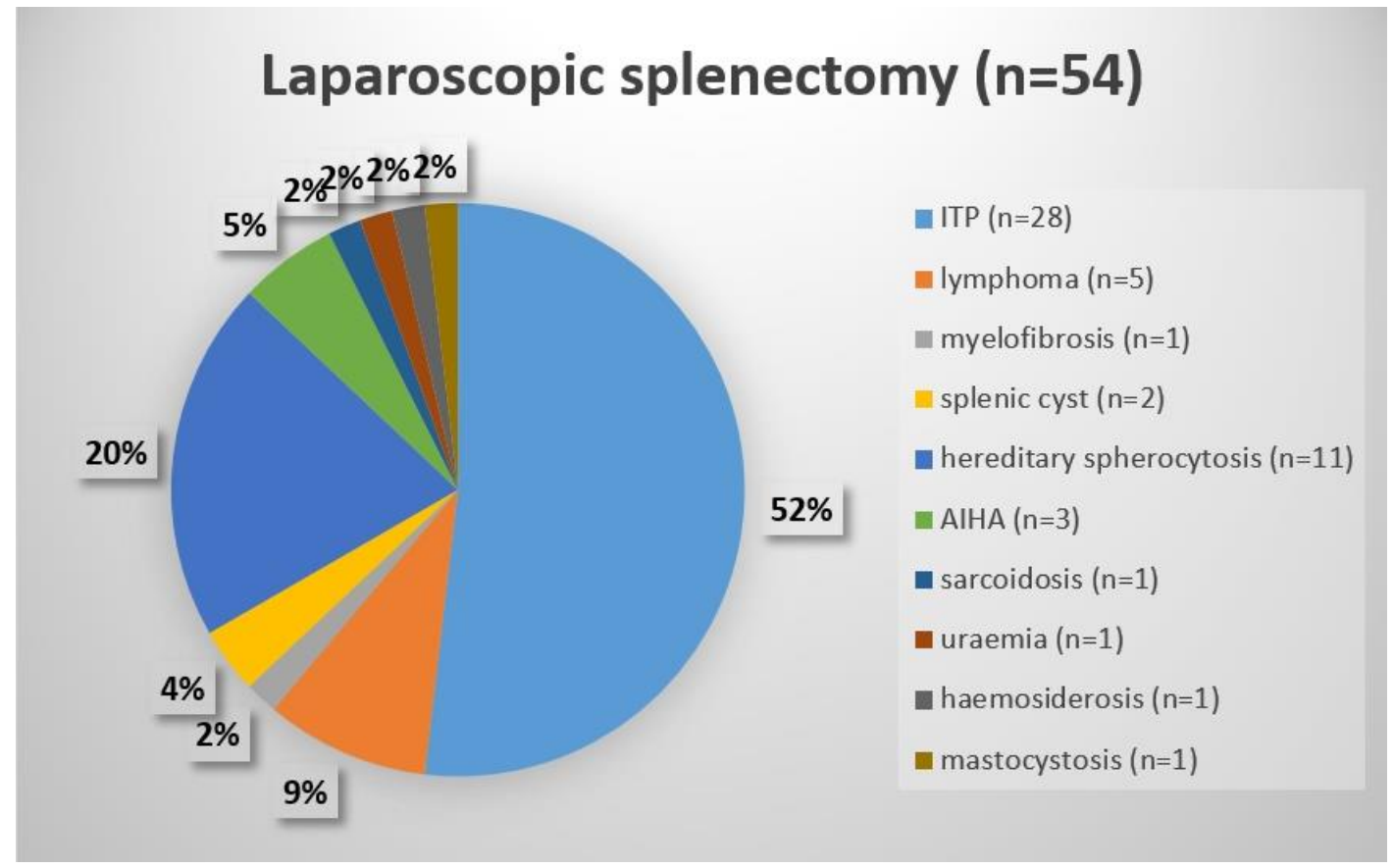

Figure 6: The indications of $L S$ 


\subsubsection{Analysis of different types of surgical methods for splenectomises}

From the aspect of the duration of surgery, there was no significant difference between the open and the laparoscopic method (Table 1).

\begin{tabular}{l|lll} 
& Laparoscopy $(\mathrm{n}=54)$ & $\begin{array}{l}\text { Open surgery }(\mathrm{n}= \\
30)\end{array}$ & $\mathrm{p}$ \\
\hline Duration of surgery (min) & $133(80-220)$ & $122(65-180)$ & $\mathrm{P}=0.074$ \\
\hline Reoperation & $1(1.9 \%)$ & $2(6 \%)$ & $\mathrm{P}=0.718$
\end{tabular}

Table 1: Results of LS and OS

Conversion from laparoscopy to open surgery was required in 4 cases $(7.4 \%)$, because of massive bleeding.

\subsubsection{Postoperative results}

There were no deaths in the perioperative period in either group. In cases of laparoscopic procedures bowel motility recovered earlier and hospital stay was shorter (Table 2).

\begin{tabular}{l|ccc} 
& Laparoscopy $(\mathrm{n}=54)$ & Open surgery $(\mathrm{n}=30)$ & \\
\hline Hospital stay (days) & 5.2 & $8.17^{*}$ & $\mathrm{p}<0.001$ \\
\hline $\begin{array}{l}\text { Time to recovery of bowel } \\
\text { function (days) }\end{array}$ & 2.4 & $3.4^{*}$ & $\mathrm{p}=0.002$ \\
\hline $\begin{array}{l}\text { Need for blood/ } \\
\text { thrombocyte transfusion } \\
\text { (patients) }\end{array}$ & $18 / 23$ & $16 / 10$ & \\
\hline
\end{tabular}

Table 2. Immediate postoperative results in the laparoscopic and open surgery groups

\subsection{Analysis of the perioperative results of patients who underwent laparoscopic} splenectomy related to spleen size, learning curve or specimen extraction method (Study II)

\subsubsection{Indications}

The indication for surgery, similarly to literature data, was idiopathic thrombocytopenic purpura (ITP) in more than $50 \%$ of the cases (in 37 cases). Furthermore, the surgery was performed because of congenital spherocytosis in 11 cases (15.7\%), lymphoma in 11 cases (15.7\%), autoimmune hemolytic anemia (AIHA) in 4 cases $(5.7 \%)$ and splenic cyst in 2 cases 
(2.9\%). Surgery was indicated because of melanoma metastasis, sarcoidosis, chronic renal failure, hemosiderosis and malignant mast cell tumor in 1 case each (1.4\%)

\begin{tabular}{|l|c|c|c|c|c|c|c|}
\hline $\begin{array}{l}\text { University of } \\
\text { Szeged (2013) }\end{array}$ & ITP & $\begin{array}{c}\text { Cong. } \\
\text { spher. }\end{array}$ & $\begin{array}{c}\text { Non-Hodgkin } \\
\text { lymphoma }\end{array}$ & $\begin{array}{c}\text { Hodgkin } \\
\text { lymphoma }\end{array}$ & AIHA & Cyst & Other \\
\cline { 2 - 7 } $\mathrm{n}=70$ & 37 & 11 & 7 & 4 & 4 & 2 & 5 \\
$(52.9 \%)$ & $(15.7 \%)$ & $(10 \%)$ & $(5.7 \%)$ & $(5.7 \%)$ & $(2.9 \%)$ & $(7.1 \%)$ \\
\hline
\end{tabular}

Table 3. Indications for surgery

\subsubsection{Surgical Procedures}

The mean duration of surgery was $122 \pm 154$ minutes with a mean duration by spleen size of 117 minutes in Group 1, 128 minutes in Group 2 and 134 minutes in Group 3. The mean duration of surgery during the learning curve was 149 minutes, followed by a mean duration of 111 minutes, which was a significant reduction $(\mathrm{p}=0.002)$.

Between January 2002 and December 2005, we used a vascular stapler $(n=15)$ for the control of the vessels in the splenic hilum. After that, the more cost-effective Hem-o-lok clips were used $(n=54)$, except for one case when the hilum was controlled with an Endo GIA because of the rupture of the splenic vein. The mean duration of surgeries with the use of a stapler was $151 \pm 105$ minutes, whereas that of the surgeries with the use of clips was $114 \pm 124$ minutes, which was a significant reduction in duration $(\mathrm{p}=0.002)$.

Conversion was performed in 5 cases $(7.1 \%)$, with the majority in the learning curve period ( 3 cases between 2002 and 2004). In these cases, the mean weight of the spleen was $463 \pm 945$ grams and the hospital stay was prolonged and reached 7.8 days.

Three intraoperative complications that could be resolved laparoscopically are worth mentioning. In one case, the already mentioned rupture of the splenic vein was treated with an Endo GIA stapler; one case of rupture of the left lobe of the liver and one case of diaphragmatic injury during the mobilization of the superior pole could be handled with laparoscopic sutures. 


\subsubsection{Postoperative results}

Reoperation was required in two cases $(2.9 \%)$ because of bleeding. The weight of the spleen was below average (138 and $403 \mathrm{~g}$ ) in these cases.

Additional perioperative morbidities occurred in three cases (pneumothorax on the first postoperative day and, in two patients, recurrent fever after the surgery). There were no cases of postoperative pancreatitis or perioperative mortality.

The mean time to bowel function recovery was two $(2.57 \pm 1.1)$ days, which showed a nonsignificant relationship with the weight of the spleen (Group 1:2.5, Group 2: 2.9, Group 3: 3.3). A correlation was also found in regard to the length of hospital stay: it was $5.1 \pm 4.8$ days on average (5, 5.2 and 5.4 days per group, respectively). The length of hospital stay was significantly reduced after the learning curve (6.15 vs. $4.7 ; \mathrm{p}=0.013)$.

\subsubsection{The effects of spleen size, learning curve and specimen retrieval method}

Based on the histological results, the mean weight of the spleens removed laparoscopically was $450 \pm 1945$ grams. Spleens considered to be of normal size $(<350 \mathrm{~g})$ were removed in 42 cases (Group 1), spleens weighing between 350 and 1000 grams in 19 cases (Group 2) and spleens over 1000 grams in 9 cases (Group 3). (Table 4)

\begin{tabular}{|c|c|c|c|c|c|}
\hline & $\begin{array}{c}\text { Group 1: } \\
<350 \mathrm{~g} \\
(\mathrm{n}=42) \\
\text { mean } \pm \mathrm{SD}\end{array}$ & $\begin{array}{c}\text { Group 2: } \\
350 \text { to } 1000 \mathrm{~g} \\
(\mathrm{n}=19) \\
\text { mean } \pm \mathrm{SD}\end{array}$ & $\begin{array}{c}\text { Group 3: } \\
1000 \mathrm{~g}< \\
(\mathrm{n}=9) \\
\text { mean } \pm \mathrm{SD}\end{array}$ & P1 value & $\mathrm{P} 2$ value \\
\hline $\begin{array}{l}\text { Duration of surgery } \\
\text { (minutes) }\end{array}$ & $117 \pm 67$ & $128 \pm 74$ & $134 \pm 59$ & 0.258 & 0.374 \\
\hline Conversion & $3(7.1 \%)$ & $1(5.3 \%)$ & $1(11.1 \%)$ & 0.479 & 0.258 \\
\hline Reoperation & $1(2.4 \%)$ & $1(5.3 \%)$ & 0 & 0.145 & 0.489 \\
\hline Hospital stay (days) & $5 \pm 4$ & $5.2 \pm 5$ & $5.4 \pm 4$ & 0.846 & 0.661 \\
\hline $\begin{array}{l}\text { Time to bowel function } \\
\text { recovery (days) }\end{array}$ & $2.5 \pm 3$ & $2.9 \pm 2$ & $3.3 \pm 3$ & 0.452 & 0.207 \\
\hline Pfannenstiel incision & $2(4.7 \%)$ & $4(21 \%)$ & $5(55.6 \%)$ & 0.845 & 0.274 \\
\hline Specimen weight (g) & $160 \pm 159$ & $578 \pm 575$ & $1494 \pm 1220$ & - & - \\
\hline
\end{tabular}

P1 value = comparison between Group 1 and Group 2; P2 value = comparison between Group 1 and Group 3

Table 4. LS results by weight of the specimen 
The importance of experience is demonstrated by the fact that whereas the mean weight of the spleens removed during the first 20 surgeries defined in the literature as the learning curve was 208 grams, it was 519 grams afterwards $(\mathrm{p}=0.02)$. We removed the first spleen weighing more than 1000 g laparoscopically in 2008. (Table 5)

\begin{tabular}{|c|c|c|c|}
\hline & Learning curve & After the learning curve & \multirow{2}{*}{$\mathrm{P}$ value } \\
\hline & $\begin{array}{c}(\mathrm{n}=20) \\
\text { mean } \pm \mathrm{SD}\end{array}$ & $\begin{array}{c}(\mathrm{n}=50) \\
\text { mean } \pm \mathrm{SD}\end{array}$ & \\
\hline $\begin{array}{l}\text { Duration of surgery } \\
\text { (minutes) }\end{array}$ & $149 \pm 95$ & $111 \pm 65$ & $0.002 *$ \\
\hline Stapler vs. clip & 15 vs. 5 & 1 vs. 49 & - \\
\hline Conversion & $3(15 \%)$ & $2(4 \%)$ & 0.125 \\
\hline Reoperation & $1(5 \%)$ & $1(2 \%)$ & 0.795 \\
\hline Hospital stay (days) & $6.15 \pm 5$ & $4.7 \pm 4$ & $0.013 *$ \\
\hline $\begin{array}{l}\text { Time to bowel function } \\
\text { recovery (days) }\end{array}$ & $2.5 \pm 3$ & $2.59 \pm 2$ & 0.674 \\
\hline Pfannenstiel incision & 0 & $11(22 \%)$ & - \\
\hline Specimen weight (g) & $208 \pm 256$ & $519 \pm 717$ & $0.02 *$ \\
\hline
\end{tabular}

Table 5. LS results by learning curve $(*: p<0.05)$

As mentioned previously, the retrieval of extremely large spleens was performed through an 8 to $10 \mathrm{~cm}$ Pfannenstiel incision without morcellation in 11 cases after 2009 (Table 6). The introduction of this procedure was required because placing the enormous spleens removed during the LS (weighing 1000 to 2000 grams based on histological findings) in a bag intraabdominally and retrieving them with morcellation would have been technically difficult and time-consuming because of the extreme size. Because of the risk of splenosis, we did not perform morcellation without placing the specimen in a bag. In these cases, the mean weight of the spleen was $1032 \pm 534$ grams with a weight over 2000 grams in two cases. 


\begin{tabular}{|l|c|c|c|}
\cline { 2 - 4 } \multicolumn{1}{c|}{} & $\begin{array}{c}\text { with Pfannenstiel } \\
\text { incision } \\
(\mathrm{n}=7) \\
\text { mean } \pm \mathrm{SD}\end{array}$ & $\begin{array}{c}\text { without Pfannenstiel } \\
\text { incision } \\
(\mathrm{n}=47) \\
\text { mean } \pm \mathrm{SD}\end{array}$ & P value \\
\hline $\begin{array}{l}\text { Duration of surgery } \\
\text { (minutes) }\end{array}$ & $108 \pm 62$ & $125 \pm 73$ & $0.05^{*}$ \\
\hline Hospital stay (days) & $4.7 \pm 3$ & $5.2 \pm 4$ & 0.178 \\
\hline $\begin{array}{l}\text { Time to bowel function } \\
\text { recovery (days) }\end{array}$ & $3.2 \pm 2$ & $2.5 \pm 3$ & 0.394 \\
\hline Specimen weight $(\mathrm{g})$ & $1032 \pm 534$ & $338 \pm 245$ & $0.0001 *$ \\
\hline
\end{tabular}

Table 6. LS results by Pfannenstiel incision (*: $p<0.05$ )

The mean duration of surgery was $108 \pm 62$ minutes, the mean time to bowel function recovery was $3.2 \pm 2$ days and the mean length of hospital stay was $4.7 \pm 3$ days. Based on the above data, the results of the cases with retrieval through a Pfannenstiel incision were not worse than those of the purely laparoscopic group; on the contrary, these interventions resulted in a shorter duration of surgery (108 vs. $125, \mathrm{p}=0.05)$ and hospital stay ( 4.7 vs. $5.2, \mathrm{p}=0.178$ ), although the time to bowel function recovery was reasonably (lower abdominal laparotomy) longer (3.2 vs. $2.5, \mathrm{p}=0.394)$. Additional factors are that better histological assessment can be performed on the intact specimen, and the Pfannenstiel incision is considered to be an acceptable cosmetic alternative (as opposed to the left subcostal or upper midline laparotomy).

\subsection{Study on the effect of Pfannenstiel incision in cases of extremely large spleens (Study III)}

Table 7 shows the effect of the Pfannenstiel incision in the group of patients with a specimen weighing more than $1000 \mathrm{~g}(\mathrm{n}=11,2$ conversion). There was no significant difference between the two removal methods.

\begin{tabular}{|l|c|c|c|}
\cline { 2 - 4 } \multicolumn{1}{c|}{} & $\begin{array}{c}\text { with Pfannenstiel } \\
\text { incision } \\
(\mathrm{n}=5) \\
\text { mean } \pm \mathrm{SD}\end{array}$ & $\begin{array}{c}\text { without Pfannenstiel } \\
\text { incision } \\
(\mathrm{n}=4) \\
\text { mean } \pm \mathrm{SD}\end{array}$ & P value \\
\hline Duration of surgery (minutes) & $121 \pm 39$ & $150 \pm 47$ & 0.31 \\
\hline Hospital stay (days) & $5 \pm 1.3$ & $6.5 \pm 2.5$ & 0.32 \\
\hline Specimen weight $(\mathrm{g})$ & $1644 \pm 613$ & $1225 \pm 209$ & 0.182 \\
\hline
\end{tabular}

Table 7. LS results by Pfannenstiel incision in cases of extremely large (>1000 g) spleens (*: $p<0.05)$ 


\subsection{Analysis of the safety of splenectomy for ITP and determining which perioperative parameters predicted long-term results using evidence-based guidelines (Study IV)}

\subsubsection{Previous treatment}

In all cases, the first-line therapy of ITP was steroid therapy. 23 cases (57.5\%) were steroidrefractory and $17(42.5 \%)$ were steroid-dependent. After this, 30 patients underwent splenectomy as second-line therapy. In 7 cases, azathioprine was administered and 3 patients received IVIG therapy as second-line therapy, followed by splenectomy.

\subsubsection{Results of surgery}

In 4 of the 40 cases (10\%), conversion was required and, finally, open surgery was performed. There was no perioperative mortality. Two patients $(5 \%)$ required reoperation for bleeding. The average duration of surgery was $113.5 \pm 62.71$ minutes. 3 of the 4 conversions were required before 2004 during the learning curve (LS was introduced at our clinic in 2000). The literature defines the learning curve as 20 surgeries for laparoscopic splenectomy, ${ }^{13}, 14$ which was exceeded in 2006, taking into account LS performed with other indications. After this, the average duration of surgeries decreased significantly from 132 to 104 minutes $(p=0.032)$. The average weight of the specimens removed was $174 \pm 89.6 \mathrm{~g}$. The average duration of postoperative care was $5.44 \pm 2.84$ days. Perioperative morbidity occurred in 4 cases, 1 patient suffered from pneumothorax, 1 experienced superficial thrombophlebitis and 2 had recurring fever.

\subsubsection{Short- and long-term haematological results of splenectomy for ITP}

The average preoperative platelet count was $66.7 \pm 47.84 \times 109 / 1$. In cases requiring the administration of platelet suspension (27), it was administered during the surgery after clipping the vessels of the spleen. On the 3rd postoperative day, the average platelet count was $148.4 \pm 93.7 \times 109 / 1$. Based on the postoperative platelet counts, complete response (CR) occurred in $28(70 \%)$ cases and a response (R) developed in $5(12.5 \%)$. A total of $82.5 \%$ of the patients responded to splenectomy in accordance with the guidelines. 7 (17.5\%) non-responder (NR) cases occurred. (Table 8)

Patient follow-up lasted an average of $10.9 \pm 6.9$ years. During this time, 2 patients died 5 and 7 years after the splenectomy, respectively (cause of death was a cardiac event in the case of an 84-year-old patient and neoplasm caused the death of a 56-year-old patient). During the followup, $21(63.6 \%)$ of the responders $(C R+R=33)$ had a permanent response. Patients with a $C R$ 
experienced a permanent response in $20 / 28$ cases (71\%), while a permanent response was achieved in 1 of 5 cases (20\%) among the R patients. Relapse occurred $12.5 \pm 7.3$ months after the splenectomy on average. The relapse rate was significantly higher in the $\mathrm{R}$ group compared with CR patients ( $80 \%$ vs. $28.6 \%$ ). R cases experienced a relapse sooner compared with the CR patients $(9.7$ vs. 18.6 months, $\mathrm{p}<0.001)$.

The 12 patients with relapse and the 7 non-responder patients underwent steroid, TPO receptor agonist (romiplostim and eltrombopag), azathioprine or IVIG therapy as further treatment.

\begin{tabular}{|c|c|c|c|}
\hline & \multicolumn{2}{|l|}{ All responses } & \multirow{2}{*}{$\begin{array}{l}\text { Non- } \\
\text { responses }\end{array}$} \\
\hline & $\begin{array}{l}\text { Complete responses } \\
(\mathrm{PLT}>100 \times 109 / 1)\end{array}$ & $\begin{array}{l}\text { Partial responses } \\
(\text { PLT } 30-100 \text { x 109/1) }\end{array}$ & \\
\hline $\begin{array}{l}\text { Number of patients }(\mathrm{n}=40) \\
(\%)\end{array}$ & $28(70 \%)$ & $5(12.5 \%)$ & $7(17.5 \%)$ \\
\hline Age (years) & $42.79 \pm 13.24$ & $49.2 \pm 18.32$ & $\begin{array}{c}60.14 \pm 24.2 \\
1\end{array}$ \\
\hline Gender (f/m) & $18 / 10$ & $5 / 0$ & $5 / 2$ \\
\hline Splenic weight (g) & $160.13 \pm 12.47$ & $206.25 \pm 10.21$ & $229 \pm 9.62$ \\
\hline $\begin{array}{l}\text { Postoperative rise of } \\
\text { thrombocyte count }(103 / \mu l)\end{array}$ & $122,5 \pm 34.2$ & $50.8 \pm 11.5$ & $8 \pm 9.62$ \\
\hline Relapse rate $(\%)$ & $8 / 28(28.6 \%)$ & $4 / 5(80 \%)$ & \\
\hline $\begin{array}{l}\text { Median time to relapse } \\
\text { (months) }\end{array}$ & 18.6 & 9.7 & \\
\hline
\end{tabular}

Table 8. General results for splenectomy in ITP patients 


\subsubsection{Predictive factors for short- and long-term response}

Based on the results above, we examined which known perioperative factors and parameters predicted short- and long-term success (Table 9).

All the patients operated on as steroid-dependent $(n=17)$ were $C R$, while patients operated on because they were steroid-refractory were classified as CR (11), R (5) and NR (7). From a different perspective, all R (5) and NR (7) patients fell into the preoperative steroid-refractory group. Significantly more NR patients were in the steroid-refractory group $(0 / 17 \mathrm{vs} 7 / 23 ; \mathrm{p}=$ $0.027)$.

Long-term results suggest that among the steroid-dependent patients $(n=17) 12$ had a persistent response $(70.6 \%)$, while 9 out of 16 patients $(56.3 \%)$ in the steroid-refractory group were persistent responders (NS).

The average age of the CR group was $42.79 \pm 13.24$, that of the R group $49.2 \pm 18.32$ and that of the NR group was $60.14 \pm 24.21$ years. Among the patients below the age of 50 years $(\mathrm{n}=$ 22), 17 were CR, 3 were R and 2 were NR. Among the patients over the age of 50 years ( $\mathrm{n}=$ 18), 11 were CR, 2 were R and 5 were NR. Therefore, in the younger group, $9 \%$ of the patients did not develop a response; this rate was $28 \%$ among the patients in the older group $(2 / 22$ vs. $5 / 18)(\mathrm{p}=0.023)$.

Long-term follow-up showed that the average age of persistent responders was $42.6 \pm 16.5$ and that of patients with relapse was $45.75 \pm 21.3$ years. Among the patients below the age of 50 years, 14 out of 20 patients were persistent responders (70\%), while this rate was 7 out of 13 among older patients (53.8\%) (NS). 


\begin{tabular}{|c|c|c|c|c|}
\hline & & \multicolumn{2}{|l|}{ All responses } & \multirow{2}{*}{$\begin{array}{l}\text { Non- } \\
\text { responses } \\
\qquad(\mathrm{n}=7)\end{array}$} \\
\hline & & $\begin{array}{c}\text { Complete responses } \\
(\mathrm{PLT}>100 \times 109 / \mathrm{l}) \\
(\mathrm{n}=28)\end{array}$ & $\begin{array}{c}\text { Partial responses } \\
(\text { PLT 30-100 x 109/1) } \\
(\mathrm{n}=5)\end{array}$ & \\
\hline \multirow{2}{*}{$\begin{array}{l}\text { Preoperative } \\
\text { steroid }\end{array}$} & $\begin{array}{l}\text {-dependent } \\
(\mathrm{n}=17)\end{array}$ & $17(100 \%)$ & 0 & 0 \\
\hline & $\begin{array}{l}\text {-refractory } \\
(\mathrm{n}=23)\end{array}$ & $11(47.8 \%)$ & $5(21.7 \%)$ & $7(30.4 \%)$ \\
\hline \multirow{2}{*}{ Age } & $\begin{array}{l}<50 \text { years } \\
(\mathrm{n}=22)\end{array}$ & $17(77.3 \%)$ & $3(13.6 \%)$ & $2(9 \%)$ \\
\hline & $\begin{array}{l}>50 \text { years } \\
(\mathrm{n}=18)\end{array}$ & $11(61 \%)$ & $2(11 \%)$ & $5(27.8 \%)$ \\
\hline \multirow{2}{*}{$\begin{array}{l}\text { Preoperative } \\
\text { platelet count }\end{array}$} & $\begin{array}{l}<30 \times 109 / 1 \\
(n=16)\end{array}$ & $7(43.75 \%)$ & $5(31.25 \%)$ & $4(25 \%)$ \\
\hline & $\begin{array}{l}>30 \times 109 / 1 \\
(\mathrm{n}=24)\end{array}$ & $21(87.5 \%)$ & 0 & $3(12.5 \%)$ \\
\hline \multirow{2}{*}{$\begin{array}{l}\text { Splenectomy } \\
\text { as a... }\end{array}$} & $\begin{array}{l}\text {...second- } \\
\text { line therapy } \\
(\mathrm{n}=30)\end{array}$ & $22(73.3 \%)$ & $3(10 \%)$ & $5(16.7 \%)$ \\
\hline & $\begin{array}{l}\text {...third-line } \\
\text { therapy } \\
(\mathrm{n}=10)\end{array}$ & $6(60 \%)$ & $2(20 \%)$ & $2(20 \%)$ \\
\hline
\end{tabular}

Table 9. Possibly predictive factors

Of the patients whose preoperative platelet count was below $30 \times 109 / 1(n=16), 7$ were in the CR group (43.75\%), 5 were in the R group (31.25\%) and 4 were in the NR group (25\%). Among the patients with a platelet count over $30 \times 109 / 1(n=24), 21$ were in the CR group $(87.5 \%)$ and 3 were in the NR group (12.5\%) (NS).

Of the 10 patients who had undergone splenectomy as a third- and not a second-line therapy (after azathioprine or IVIG therapy), the surgery was performed after an average of $17.75 \pm 3.43$ months following the diagnosis, which is surprisingly shorter compared with the average value of all the patients. Of these 10 patients, 6 were CR, 2 were R and 2 were NR (NS). 
In summary, response to first-line steroid therapy (dependency) $(p=0.027)$ and younger age $(p$ $=0.023)$ proved to be more effective in predicting short-term efficacy of splenectomy based on logistic regression analysis (Table 10).

\begin{tabular}{|l|c|c|c|}
\hline Factor & OR & $95 \%$ CI & p value \\
\cline { 1 - 4 } Preoperative steroids & 1.265 & $1.063-1.496$ & 0.027 \\
\cline { 1 - 3 } Age & 1.359 & $1.0370-1.771$ & 0.023 \\
\hline
\end{tabular}

Table 10. Results of logistic regression analysis in the NR subgroups

None of the parameters examined and listed in Table 8 predicted long-term haematological outcomes, although we confirmed that the extent of the immediate response was a good predictor of long-term results, which is often described in the literature as well: $71 \%$ permanent response for $\mathrm{CR}$ and $20 \%$ for $\mathrm{R}(\mathrm{p}<0.001)$. 


\section{DISCUSSION}

\subsection{A history of splenectomy}

For millennia, the spleen has been considered a fascinating and mysterious organ with more functions than any other. It has long been an organ of interest. Most famous scientists had their own theory of its function. According to Plato, the spleen was created in order "to maintain the liver bright and pure". In ancient Greece, Hippocrates, in his Aphorisms, described with remarkable accuracy the anatomy of the spleen, also recognizing its indispensable role in life, since it produced the "black bile", one of the four vital humors. However, there were some who considered the spleen a simple counterbalance, "to balance the left part of the body with the right", but many considered it "a useless Organ, to be eliminated!". ${ }^{20}$

During the centuries, there were more and less successful attempts to perform splenectomies, especially because of traumatic causes. The first description of a traumatic hernia of the spleen is attributed to Ambroise Paré de Laval (1545). However, besides traumatic causes, in 16th century they suspected a benign effect of splenectomy in hematological diseases. Fioravanti reports that splenectomy was performed in Italy in 1549 by the old Neapolitan surgeon Adriano Zaccaria on a 24-year-old lady with malarial splenomegaly: "The spleen weighed 1340 grams; the recovery was 24 days".

The first splenectomy for a tumorous spleen was performed by Quittembaum in 1826: "an organ of 6 libra of weight in an ascitic woman of 22 years". Franzolini, in Italy, reported in 1881: "I extirpated the organ in a woman of 22 years with aplastic anemia and the medical examination, practised many months after, showed a normal relationship between leucocytes and red corpuscles". ${ }^{21,22}$

Between 1905 and 1926, Lord Berkeley Moynihan, who would be president of the Royal College of Surgeons of England from 1926 to 1930, published four editions of his book Abdominal operations, defining medical indications for splenectomy that ranged from leukemia to Hodgkin's disease, from pernicious anemia to Gaucher's disease. ${ }^{23}$ With improvements in anesthesia, surgical techniques, hematology and oncology the mortality and morbidity have decreased. Recently, laparoscopic resection and partial resection of the spleen have become fairly commonplace. The technique was first described in 1992 and has become a well-accepted procedure. ${ }^{1,24}$ In fact, at the present time, laparoscopic splenectomy is the "gold standard" for the surgical treatment of immune thrombocytopenia purpura. ${ }^{25}$ 


\subsection{Open vs. laparoscopic splenectomy (Study I)}

The laparoscopic splenectomy was first described in 1992 by Delaitre and Maignien. Since its introduction, LS has become the gold standard because of its numerous known advantages over open surgery (OS).

The advantages of the minimally invasive technique generally include a shorter hospital stay, less postoperative pain, a shorter time for recovery of the bowel function, fewer incisional hernias and a better cosmetic result, but it has the disadvantage of a longer duration of surgery. Laparoscopic splenectomy is indicated for most benign and malignant hematologic diseases independently of the patient's age and body weight. The expert panel still considers portal hypertension and major medical comorbidities as contraindications to LS. ${ }^{16}$ Several systematic reviews have confirmed the advantages of the LS over the open technique, e.g. the metaanalyses of Winslow ${ }^{2}$ and Bay, ${ }^{3}$ which show a uniformly lower complication rate, shorter hospital stay, reduced blood loss and longer duration of surgery in a population of about 3000 patients. Cheng, in a comprehensive meta-analysis based on a 15-year literature, found that, technically, LS should be recommended as a prior remedy with its advantage of rapid recovery and minimal physical damage, in addition to its comparable surgical efficacy compared to that of open manipulation. ${ }^{26}$

Similarly, in our study, LS was found to be not significantly longer than OS (133 vs. 122 minutes, $\mathrm{p}=0,074)$. In cases of laparoscopic procedures bowel motility recovered earlier ( $2 \mathrm{vs}$. 3 days, $\mathrm{p}=0,002$ ) and hospital stay was significantly shorter ( 5 vs. 8 days, $\mathrm{p}<0,001$ ).

\subsection{The effect of the learning curve (Study II)}

One of the most important factors in our study was the experience of the team. Several publications in the literature focus on this topic: Cusick has investigated the importance of the learning curve after 49 cases of splenectomy in children. He found significant reduction in the duration of surgery, intraoperative blood loss and hospital costs when comparing the results of the first and last 10 patients and established the limit, after which the duration of surgery and the costs were reduced owing to the experience in 20 surgeries. $^{8}$ Peters et al. have defined the learning curve studying surgeries performed because of ITP. After sorting 50 surgeries into groups of ten in chronological order, they have concluded that the duration of surgery of patients in the first 2 groups was significantly longer than that in groups 3, 4 and 5. No difference was found in blood loss, hospital stay and time to oral feeding and the learning curve was defined 
as performing at least 20 surgeries. $^{9}$ In our study, the duration of surgery and the length of hospital stay significantly decreased after the learning curve.

For the control of the vessels in the splenic hilum, we initially used a vascular stapler, and after 2006, we employed individual vessel dissection and clips, similarly to the method described by Tan in their paper published in $2013 .{ }^{17}$ Similarly to Tan, we found the method to be safe, especially in the case of splenomegaly when the positioning of the stapler would be difficult because of the reduced space. There are papers about managing the splenic hilum with a LigaSure instrument or a Harmonic scalpel only, ${ }^{27,28}$ but this method was not employed by our work group.

\subsection{Special issue -large spleens}

The publications related to the topic uniformly consider it a standardized, safe method in the case of a normal-sized spleen. In the case of massive splenomegaly, however, the opinion is divided. Targorana et al. have found a correlation between spleen weight and conversion rate: compared to the mean rate of $6.7 \%$, a conversion rate of $25 \%$ was observed in the case of massive splenomegaly. ${ }^{29}$ With a conversion rate of $13.3 \%$, Sapucahy et al. have recommended the laparoscopic procedure for smaller spleens. ${ }^{30}$ Poulin does not recommend the laparoscopic method over a craniocaudal diameter of $20 \mathrm{~cm}$ and a weight over 1000 grams. ${ }^{31}$ The already mentioned paper of Bai et al., summarizing 39 trials and 1,540 patients subjected to laparoscopic splenectomy, defines massive splenomegaly as a spleen weight over $1 \mathrm{~kg}$, and finds longer duration of surgery, higher conversion rate, higher blood loss, longer hospital stay and an increased rate of perioperative complications, each of which is considered to be preventable in the case of an experienced surgeon. ${ }^{3}$ Furthermore, several recent publications have supported that LS is a safer and more effective method than OS also in the case of massive splenomegaly. ${ }^{32,33,34}$ These results were also supported by a systematic review performed on 1,500 patients. $^{6}$

In the case of massive splenomegaly, the main complication is severe bleeding, which is also the main cause of conversions and re-operations. Different sources estimate the conversion rate to be in the range of 6 to $36 \% .{ }^{35,36,37}$ In our study it was $7.1 \%$, and conversions were performed mainly in the learning curve period. In our study, the large spleen had no effect on the conversion rate and, although there was a trend of increase in duration of surgery and hospital stay in the case of larger spleens, there was no significant difference between the groups. 
Several authors have found that the difficulties related to larger spleen size can be resolved with the use of hand-assisted laparoscopic splenectomy (HALS). In a paper published in 2007, Wang observed a shorter duration of surgery, lower blood loss and a reduced conversion rate in the case of HALS compared to conventional LS. ${ }^{38}$ Similar results were presented in the case of complicated splenectomies (supramassive splenomegaly, portal hypertension) as well in their paper published in 2013. ${ }^{39}$ According to Targorana et al., the hand-assisted technique decreased the length of hospital stay (4 vs. 6.3 days), morbidity was lower (10\% vs. 36\%), and the duration of surgery was shorter (135 minutes vs. 177 minutes) in the case of a spleen weighing more than 700 grams. ${ }^{40}$ When studying the complications of laparoscopic splenectomy, Wang et al. observed a lower postoperative complication rate in the case of HALS (in subxiphoid position) compared to the purely laparoscopic group (OR: 22.311 vs. 6.713). ${ }^{41}$

In the clinical practice guidelines of the EAES in cases of massive splenomegaly, the handassisted technique should be considered to avoid conversion to open surgery and to reduce complication rates. ${ }^{16}$

\subsection{Retrieving enlarged spleens}

Retrieving a large-sized spleen from the abdominal cavity may also be difficult during LS. In general, placing the specimen in a retrieval bag and intraabdominal morcellation are recommended. At the end of the procedure, a thorough rinsing of the abdominal cavity with saline is recommended to avoid splenosis, and a color Doppler scan is to be performed within 3 months. ${ }^{34,42}$

The Pfannenstiel incision is a known adjunct to several types of laparoscopic surgery. There have been relatively few papers published on its role in the laparoscopic surgery of the spleen and the retrieval of the specimen, and those identify the Pfannenstiel incision rather than the site for insertion of the hand port. ${ }^{43,44} \mathrm{We}$ suppose that a hand port introduced through a Pfannenstiel incision for left upper abdominal surgery leads to unnecessary inconveniences, especially in the case of a right-handed surgeon. Besides, eliminating the use of the hand port reduced the costs during our study.

There is only one publication, the paper of Patle (2010) on making a Pfannenstiel incision for the sole purpose of retrieving the specimen after purely laparoscopic splenectomy, which includes 50 patients operated on due to $\beta$-thalassemia. ${ }^{7}$ The specimen was retrieved through a 7 to $8 \mathrm{~cm}$ Pfannenstiel incision in 37 cases and with the extension of the umbilical port site in 12 cases and conversion was performed in one case. In the case of retrieval through the 
Pfannenstiel incision, similarly to our results, a significantly shorter duration of surgery was observed, and the procedure is considered a cosmetically acceptable alternative.

If the specimen could not be placed in a bag because of its extreme size, our work group retrieved it in whole through a Pfannenstiel incision. Because of the risk of splenosis, we performed intraabdominal morcellation only after placing the specimen in an Endobag. It is especially important in the treatment of hematological malignancies of the spleen, because of the need of pathological characterization of malignant disease. ${ }^{45,46}$ On the other hand, in malignancies splenomegaly is more characteristic, therefore most malignant cases required an accessory incision (47\% Pfannenstiel in our study) at the end of the procedure to extract the intact spleen.

\subsection{Splenectomy in the treatment of ITP (Study IV)}

In steroid-refractory and steroid-dependent ITP patients, splenectomy provides the best and most permanent results as a second-line therapy compared with medicinal therapy (TPO mimetics and rituximab). ${ }^{15,47,48}$

A splenectomy exerts its effect by removing the primary site of platelet destruction and partly by removing an important site of antiplatelet antibody production, with the response rate reported at an average of $80 \%$ and the rate of permanent responders approximately $60 \% .13,15,49$ In a systematic review of 135 cases published in 2004, the response rate was $88 \%$ and a complete response was found in $66 \%$ of them, with a median follow-up duration of 28 months. ${ }^{12}$ In a systematic review of laparoscopic splenectomies published in 2009, the conversion rate of the 1,223 patients examined was $5.6 \%$, and the success rate was $72 \% .{ }^{50}$ In our study, CR was $70 \%(\mathrm{n}=28)$ and $\mathrm{R}$ occurred in $12.5 \%(\mathrm{n}=5)$ of the cases; that is, a total of $82.5 \%$ of the patients responded to splenectomy performed in accordance with the guidelines. This rate was not influenced by whether the splenectomy was done as a second- or third-line therapy. In patients treated with azathioprine or IVIG after steroid treatment, CR was achieved in $60 \%$ after splenectomy, R occurred in $20 \%$ after the surgery and the NR rate was $20 \%$. These rates are consistent with the results found after examining all the patients; therefore, previous treatment did not influence the efficacy of the splenectomy.

After a follow-up of an average of 9.92 years, $63.6 \%$ of the responder patients $(\mathrm{CR}+\mathrm{R}=33)$ had a permanent response $(n=21)$, which correlates with the known rate of one-third of patients showing a response initially developing a relapse later as well. ${ }^{12,47}$ 
If relapse occurs after splenectomy, based on the literature data, it takes place after 12-48 months. After this time, it only occurs sporadically. ${ }^{47}$ Our study confirmed this result. In our patients, relapse developed after an average of 12.5 months and no relapse was detected after 47 months.

Alternative options for second-line therapy are medications such as rituximab or TPO-RAs. The long-term efficacy of these therapies is less than that of splenectomy. Rituximab (a chimeric monoclonal antibody against CD20) has an immediate efficacy of 50-65\%, although relapse occurs frequently; therefore, the long-term response after 12 and 24 months is only between 20 and $30 \% .^{51,52}$

In 2015, a multicentre, randomized, double-blind, placebo-controlled study was published in the Lancet describing a long-term response rate for rituximab similar to that of the placebo. ${ }^{53}$ A study published in 2016 comparing the results for splenectomy and rituximab therapy found splenectomy to be more effective (the 30-month primary outcome-free survival rate was $84-86 \%$ vs. $47 \%, \mathrm{p}=0.0002){ }^{14}$ TPO agonists exert their effect by enhancing platelet production, not by modulating the immune system. TPO agonists stimulate platelet production of megakaryocytes. A response rate of $59-80 \%$ can be achieved with these medications, however, a great disadvantage of these products is that they are expensive and that permanent treatment is required, since withdrawal of therapy leads to the recurrence of thrombocytopenia. ${ }^{48,54,55}$

With regard to the splenectomy technique, several publications are available comparing LS and OS. It can be concluded that LS and OS are similarly effective from a hematological point of view. ${ }^{56} \mathrm{Qu}$ et al. performed open and laparoscopic splenectomies and no significant difference was found for relapse-free survival during a 36-month follow-up (86\% vs. 91\%, respectively, $\mathrm{p}=0.792) .{ }^{13}$ Chater et al. reached similar results for 30 -month event-free survival, with no difference found between LS and OS (86\% vs. 84\%). ${ }^{14}$ In a systematic review conducted on 47 case series in 2004 , a lower mortality rate (1\% vs. $0.2 \%)$ and fewer complications $(12.9 \%$ vs. 9.6\%) were observed for LS. ${ }^{12}$ The main limitation of the laparoscopic technique is splenomegaly, although our previous results showed that laparoscopic splenomegaly was not contraindicated even in the case of extreme splenomegaly (spleen weighing over 2000 grams). Splenomegaly causing technical difficulties is not characteristic of ITP; therefore, this limiting factor is not common either. 


\subsubsection{Potential predictive factors of the efficacy of splenectomy}

There are several publications about potential predictive factors that may be determined before splenectomy and that may be used to predict long-term results for the surgery as well. The most widely accepted predictive factors are younger age, steroid dependency and non-refractory states, as well as higher platelet count before surgery and splenic sequestration. In our study, no data was available for splenic sequestration, so results were analysed using the other factors.

Our study confirmed the predictive value of younger age described in the literature. $57,58,59,60$ The average age of the CR group was $42.79 \pm 13.24$ years, that of the R group $49.2 \pm 18.32$ years and that of the NR group $60.14 \pm 24.21$ years. Long-term follow-up for persistent responders showed an average age of $42.6 \pm 16.5$ years and patients developing a relapse were $45.75 \pm 21.3$ years old on average. The response rate for patients below the age of 50 years (n $=22)$ was $90.1 \%(77.3 \% \mathrm{CR}$ and $13.6 \% \mathrm{R})$, while this rate was $72.2 \%(61.1 \% \mathrm{CR}$ and $11.1 \%$ $\mathrm{R})$ in patients over the age of $50(\mathrm{n}=18)$. There were significantly more NR patients in the older group ( $\mathrm{p}=0.023$ ). In addition, $70 \%$ of the patients below the age of 50 showing a response at first also had a permanent response, while this rate was only $53.8 \%$ in older patients. Shojaiefard et al. found results similar to ours; in their study, patients below the age of 52 responded to splenectomy more positively compared to elderly patients $(\mathrm{p}<0.01) .{ }^{57}$ Fabris et al. confirmed age below 40 years to be the only major predictive factor in a similar investigation. ${ }^{58}$ However, several opposite results are found in the literature as well: Vianelli et al. studied 233 patients for more than 10 years and found no link between age and response to splenectomy ${ }^{47}$ and, similarly, Rijcken et al. had negative results for the predictive value of age in their examination of 72 patients. ${ }^{61}$

Several studies have analysed the predictive role of response to preoperative steroids. ${ }^{61,62,63} \mathrm{In}$ our study, all the patients operated on as steroid-dependent $(\mathrm{n}=17)$ were in the CR group, although all the R (5) and NR (7) patients fell into the preoperative steroid-refractory group. There were significantly more NR patients in the steroid-refractory group $(p=0.027)$. In the case of patients showing a persistent response $(n=21), 12$ were steroid-dependent and 9 were steroid-refractory patients; in the loss of response group $(n=12)$ there were 5 steroid-dependent and 7 steroid-refractory patients. Rijcken, ${ }^{61}$ Aleem ${ }^{62}$ and Radaelli, ${ }^{63}$ among others, found response to steroids to be a predictive factor in their studies.

Perhaps the least controversial fact is that complete response (CR) significantly predicts the probability of a long-term stable response. ${ }^{61,64}$ Wang et al. followed up 92 patients and found 
the platelet count in the 3rd postoperative month to be an independent predictor of long-term outcome. ${ }^{65}$ Rijcken found a greater increase in platelet count in the postoperative period $(>150,000 / \mu 1)$ to be a predictor of long-term response. ${ }^{61}$ Montalvo examined 150 patients and found an immediate response after surgery $(\geq 150,000)$ to be the one-year CR predictor. ${ }^{66} \mathrm{In}$ addition, Vianelli followed up 233 patents for at least 10 years and confirmed no stable predictors of long-term response. ${ }^{47}$ During our follow-up, we concluded the same findings. While results were found to be permanent in $71 \%$ of the CR patients, a permanent response only occurred in $20 \%$ of the patients in the partial response group.

In the future, lifespan and sequestration studies of platelets labelled with Indium would be useful (if the splenic literature data shows that splenectomy is effective in $90 \%$ of cases), ${ }^{64,67,68}$ although such data is not available in our study.

The role of an accessory spleen in the recurrent disease is also an intensively investigated issue. In a review article summarizing data of 22,000 people, the overall pooled prevalence of AS was $14.5 \%$, while the pooled prevalence of AS in ITP patients was $16.7 \%$. The majority of accessory spleens were located in the splenic hilum. ${ }^{69}$ The relapse of thrombocytopenia post-splenectomy can be associated with the presence of an accessory spleen. ${ }^{70}$ In our study we had limited information about the presence of remnant AS because of the lack of postoperative screening ultrasound, therefore we could not analyse this issue.

Finally, we compared our results to the literature data and examined both (a) the number of published studies that used the consensus guidelines to follow patients in the long term after laparoscopic splenectomy since the 2011 introduction of the standardized guidelines ${ }^{19}$ and (b) the predictive factors in these publications.

Xu et al. analysed 114 patients in their 2016 study, in which age and postoperative peak platelet count were independently associated with the response. ${ }^{71}$ Vecchio also examined patients with laparoscopic and open surgeries for a 2015 article and found that a higher increase of postoperative platelet count may be predicted in patients with a low preoperative platelet count. ${ }^{72}$ In the investigation by Rijcken with 72 patients (noted above), perioperative platelet counts were predictive factors of long-term response. ${ }^{61}$ Navez studied 82 patients in 2014 , primarily examining the predictive value of platelet sequestration; the platelet sequestration site was not found to be a predictive factor, but age was. ${ }^{73}$ Montalvo reviewed data on 150 patients and found no predictive factors of long-term permanent response besides immediate complete response (response $>150,000$ platelets/ml during the first week). ${ }^{66}$ In the 2013 article by Wang 
noted above, the platelet count in the 3rd postoperative month (POM 3) was a significant independent predictor of long-term favourable hematological outcomes. ${ }^{65}$

In summary, literature data have been exceedingly heterogeneous with regard to predictive factors, even since the consensus guidelines were published. In addition, potentially prospective studies are necessary to determine predictive factors. Furthermore, long-term follow-up of patients with various imaging techniques is important to screen the accessory spleen and its possible role in nonresponsive and refractory ITP.

\subsubsection{Reasons against splenectomy: potential complications of splenomegaly}

With second-line medicinal therapy, the possibility of peri- or postoperative or late complications of splenectomy is often emphasized. ${ }^{47}$ In our study, complications were only observed after splenectomy in 2 cases, with the patients experiencing bleeding that required reoperation. No complication occurred besides reoperation due to bleeding in $5 \%$ of the patients, although surgery was performed with a platelet count of 5000/ml in several (3) patients. Several publications have analysed the safety of surgeries performed with a low platelet count. Cai et al. compared the results of laparoscopic splenectomy patients with a platelet count below $10 \times 109 / 1$ (Grade 1) with those of patients operated on with a higher platelet count (Grade 2: 10-30 x 109/1; Grade 3: >30 x 109/1). ${ }^{74}$ Our results showed that blood loss or the number of complications was not significantly increased and the duration of hospitalization was not significantly prolonged in patients operated on with a lower platelet count. Wu et al. examined surgical patients with a platelet count below 20 x 109/l and found no difference with regard to the outcome of the surgery in a comparison of patients not receiving preoperative platelet transfusion and those receiving preoperative platelet transfusion. ${ }^{75}$ In our case, reoperation was performed on 2 patients with platelet counts of 36 x 109/1 and 42 x 109/1.

No pancreatitis, perioperative infection or suppuration occurred. Patients undergoing splenectomy are more susceptible to infections and vascular complications in the long term. Increased risk of infections is confirmed in patients undergoing splenectomy. In a Danish cohort study, susceptibility to infections among 3,812 patients having had splenectomy was compared with that of 8,310 matched non-splenectomized patients and that of 38,120 control patients. The risk rate for sepsis increased fourteen-fold in patients undergoing splenectomy during the first year compared with the general population; after one year, the risk rate decreased to four times. Comparing the results with those of non-splenectomized ITP patients, an increased risk rate of sepsis was only found during the first 90 days. ${ }^{76}$ Perioperative vaccination, patient education 
on the risk of overwhelming sepsis and the use of antibiotic prophylaxis greatly aid in preventing septic complications. For instance, Vianelli et al. examined 402 patients in their study and did not report sepsis-related mortality. ${ }^{77}$ In our study, no sepsis-related mortality occurred.

In addition to the risk of infection, other potential complications are vascular complications. The thrombocytopenia for ITP makes patients susceptible to thromboembolisation in accordance with the literature data; ${ }^{78}$ in addition, splenectomy increases the risk of venous thromboembolisation. ${ }^{79}$ In our study, with prophylactic LMWH administered permanently, no deep venous thrombosis was confirmed, only one superficial thrombophlebitis.

In our investigation, surgery-related morbidity was not significant, and due to potential risks, estimation of response is very useful in considering surgery based on predictive parameters. 


\section{CONCLUSION}

(1) Our working group was the first to publish a comprehensive study with different aspects of the minimal invasive surgery of the spleen in Hungary.

Based on our results, similarly to literature data, it may be established that laparoscopic splenectomy can be considered a surgical procedure with low morbidity after gaining the necessary experience. In our study, the bowel motility recovered earlier and hospital stay was significantly shorter after laparoscopic procedures.

(2) Laparoscopic splenectomy is a safe method in cases of extremely large spleens.

(3) In the case of massive splenomegaly, the Pfannenstiel incision may be a cosmetically more acceptable alternative for the retrieval of the spleen than the mini laparotomy performed for the hand port inserted in the upper abdominal region during HALS and surgical costs may also be reduced by restricting the use of the hand port. In addition to the above, a shorter duration of surgery, prevention of splenosis and an improved histological assessment of the specimen might be expected from the use of the Pfannenstiel incision.

(4) Although several medications are available for second-line ITP therapy, splenectomy provides the longest-lasting results. Laparoscopic splenectomy is the gold standard, as it can be performed safely and with great efficacy in centres experienced in the technique. In our study, young age and a preoperative response to steroids (steroid-dependent cases) were positive predictors for the success of splenectomy.

(5) In the case of an immediate complete response to splenectomy, relapse occurred significantly less often during long-term follow-up. 


\section{ACKNOWLEDGEMENTS}

I would like to express my sincere gratitude to those who have supported me during my scientific work.

György Lázár, Professor and Head of the Department of Surgery, University of Szeged, and Member of the Hungarian Academy of Sciences. With your vast knowledge and continuous support, you gave me a secure background in my research work. Thank you for your excellent scientific guidance you have provided since my undergraduate years.

I would also like to thank Andrea Vida for her endless patience and help in editing articles.

My colleagues and friends

Ágnes Bereczki, Dóra Földeák, my co-authors. Thank you for your indispensable help during the ITP study. Attila Paszt, Zsolt Simonka, Szabolcs Ábrahám, Bernadett Borda, Eszter Mán, my colleagues and co-authors, thank you for all the help you gave me during the studies. I am also grateful to Enikő Veres-Lakos for her help during the preparation of this manuscript. I wish to express my special gratitude to my family an especially to my Mother, Katalin Barna for showing me how to live a deeply valuable life. 


\section{REFERENCES}

1 Delaitre B, Maignien B, Icard P. Laparoscopic splenectomy. Brit J Surg 1992;79:1334.

2 Winslow ER, Brunt LM. Perioperative outcomes of laparoscopic versus open splenectomy: a meta-analysis with an emphasis on complications. Surgery 2003;134:647-653.

3 Bai YN, Jiang H, Prasoon P. A meta-analysis of perioperative outcomes of laparoscopic splenectomy for hematological disorders. World J Surg 2012;36:2349-2358.

4 Kanyári Z, Kincses Z, Orosz L, Juhász B, Tanyi M, Lukács G, Damjanovich L. [Increasing dominance of laparoscopic techniques in the surgery of the spleen in hematologic syndromes]. Magy Seb. 2006;59(1):7-11. [Article in Hungarian]

5 Bognár G, István G, Ledniczky G, Barabás L, Ondrejka P. [Analysis of two different operative techniques for laparoscopic splenectomy]. Magy Seb. 2010;63(6):359-63. [Article in Hungarian]

6 Ardestani A, Tavakkoli A. Laparoscopic versus open splenectomy: the impact of spleen size on outcomes. J Laparoendosc Adv Surg Tech A 2012;23:760-764.

7 Patle NM, Tantia O, Sasmal PK, Khanna S, Sen B. Laparoscopic splenectomy in patients of $\beta$ thalassemia: Our experience. J Minimal Access Surg 2010;6:70-75.

8 Cusick RA, Waldhausen JH. The leaning curve associated with pediatric laparoscopic splenectomy. Am.J. Surg 2001;181:393-397.

9 Peters MB Jr, Camacho D, Ojeda H, Reichenbach DJ, Knauer EM, Yahanda AM, Cooper SE, Sweeney JF. Defining the learning curve for laparoscopic splenectomy for immune thrombocytopenia purpura. Am J Surg 2004;188:522-525.

10 Lo E, Deane S. Diagnosis and classification of immune-mediated thrombocytopenia. Autoimmun Rev 2014;13:577-583.

11 Tsereteli Z, Smith CD, Branum GD, Galloway JR, Amerson RJ, Chakaraborty H, Hunter JG. Are the favorable outcomes of splenectomy predictable in patients with Idiopathic thrombocytopenic purpura (ITP)? Surg Endosc 2001;15:1386-1389.

12 Kojouri K, Vesely SK, Terrell DR, George JN. Splenectomy for adult patients with idiopathic thrombocytopenic purpura: a systematic review to assess long-term platelet count responses, prediction of response, and surgical complications. Blood 2004;104:2623-2634. 
$13 \mathrm{Qu} \mathrm{Y,} \mathrm{Xu} \mathrm{J,} \mathrm{Jiao} \mathrm{C,} \mathrm{Cheng} \mathrm{Z,} \mathrm{Ren} \mathrm{S.} \mathrm{Long-term} \mathrm{outcomes} \mathrm{of} \mathrm{laparoscopic} \mathrm{splenectomy}$ versus open splenectomy for idiopathic thrombocytopenic purpura. Int Surg 2014;99:286-290. 14 Chater C, Terriou L, Duhamel A, Launay D, Chambon JP, Pruvot FR, Rogosnitzky M, Zerbib P. Reemergence of Splenectomy for ITP Second-line Treatment? Ann Surg 2016;264:772-777.

15 Zheng D, Huang CS, Huang SB, Zheng CX. Laparoscopic splenectomy for primary immune thrombocytopenia: Current status and challenges. World J Gastrointest Endosc 2016;8:610 615.

16 Habermalz B, Sauerland S, Decker G et al. Laparoscopic splenectomy: the clinical practice guidelines of the European Association for Endoscopic Surgery (EAES). Surg Endosc 2008;22:821-848.

17 Tan J, Chu Y, Tan Y, Dong J. Stapleless laparoscopic splenectomy with individual vessel dissection in patients with splenomegaly. World J Surg 2013;37:2300-2305.

18 Rodeghiero F, Stasi R, Gernsheimer T et al. Standardization of terminology, definitions and outcome criteria in immune thrombocytopenia purpura (ITP) of adults and children: report from an International working party. Blood. 2009;113:2386-2393.

19 Neunert C, Lim W, Crowther M, Cohen A, Solberg L Jr, Crowther MA. The American Society of Hematology 2011 evidence-based practice guideline for immune thrombocytopenia. Blood 2011;117:4190-4207.

20 Morgenstern L. A history of splenectomy. In: Hiatt JR, Phillips EH, Morgenstern L, editors. Surgical diseases of the spleen . New York: Springer; 1997.

21 McClusky DA 3rd, Skandalakis LJ, Colborn GL, Skandalakis JE. Tribute to a triad: history of splenic anatomy, physiology, and surgery - part 1. World J Surg 1999; 23(3):311-25.

22 McClusky DA 3rd, Skandalakis LJ, Colborn GL, Skandalakis JE. Tribute to a triad: history of splenic anatomy, physiology, and surgery - part 2. World J Surg 1999; 23(5):514-26.

23 Dionigi R, Boni L, Rausei S, Rovera F, Dionigi G. History of splenectomy Int J Surg 2013;11(S1), S42-S43.

24 Carroll BJ, Phillips EH, Semel CJ, Fallas M, Morgenstern L. Laparoscopic splenectomy. Surg Endosc 1992;6:183-5. 
25 Friedman RL, Fallas MJ, Carroll BJ, Hiatt JR, Phillips EH. Laparoscopic splenectomy for ITP. The gold standard. Surg Endosc 1996;10:991-5.

26 Cheng J, Tao K, Yu P. Laparoscopic splenectomy is a better surgical approach for spleenrelevant disorders: a comprehensive meta-analysis based on 15-year literatures. Surg Endosc. 2016;30(10):4575-88.

27 Fujioka S, Yoshida K, Okamoto T, Yanaga K. Stapleless laparoscopic splenectomy using harmonic scalpel by 2-step sealing. Int Surg 2013;98:385-387.

28 Shabahang H, Maddah G, Tavassoli A, Jangjoo A, Alvandipour M, Abdollahi A, Noorshafiee S. Laparoscopic splenectomy: ligasure or clip ligation? Surg Laparosc Endosc Percutan Tech 2012;22:136-138.

29 Targarona EM, Espert JJ, Balague C, Piulachs J, Artigas V, Trias M. Splenomegaly should not be considered a contraindication for laparoscopic splenectomy. Ann Surg 1998;228:35-39. 30 Sapucahy MV, Faintuch J, Bresciani CJ, Bertevello PL, Habr-Gama A, Gama-Rodrigues JJ. Laparoscopic versus open splenectomy in the management of hematologic diseases. Rev. Hosp. Clín. Fac. Med. S. Paulo 2003;58:243-249.

31 Poulin Ec, Thibault C. Laparoscopic splenectomy for massive splenomegaly: operative technique and case report. Can J Surg 1995;38:69-72.

32 Owera A, Hamade AM, Bani Hani OI, Ammori BJ. Laparoscopic versus open splenectomy for massive splenomegaly: a comparative study. J Laparoendosc Adv Surg Tech A 2006;16:241-246.

33 Grahn SW, Alvarez J 3rd, Kirkwood K. Trends in laparoscopic splenectomy for massive splenomegaly. Arch Surg 2006;141:755-761.

34 Jin Zhou, Zhong Wu, Yunqiang Cai, Yichao Wang, Bing Peng. The Feasibility and Safety of Laparoscopic Splenectomy for Massive Splenomegaly: A Comparative Study. Journal of Surgical Resarch 2011;171:55-60.

35 Patel AG, Parker JE, Wallwork B, Kau KB, Donaldson N, Rhodes MR, O'Rourke N, Nathanson L, Fielding G. Massive splenomegaly is associated with significant morbidity after laparoscopic splenectomy. Ann Surg 2003;238:235-240. 
36 Rosen M, Brody F, Walsh RM, Ponsky. Hand-assisted laparoscopic splenectomy vs conventional laparoscopic splenectomy in cases of splenomegaly. Arch Surg 2002;137:13481352.

37 Donini, Baccarani U, Terrosu G, Corno V, Ermacora A, Pasqualucci A, Bresadola F. Laparoscopic vs open splenectomy in the management of hematologic diseases. Surg Endosc 1999;13:1220-1225.

38 Wang, Hu SY, Zhang GY, Chen B, Zhang HF. Hand-assisted Laparoscopic splenectomy for splenomegaly: a comparative study with conventional Laparoscopic splenectomy. Chinese Medical Journal 2007;120:41-45.

39 Wang X, Li Y, Peng B. Hand-assisted laparoscopic technique in the setting of complicated splenectomy: a 9-year experience. World J Surg 2013;37:2046-2052.

40 Targorana EM, Balague C, Cerdán G, Espert JJ, Lacy AM, Visa J, Trias M. Hand-assisted Laparoscopic splenectomy (HALS) in cases of splenomegaly: a comparison analysis with conventional Laparoscopic splenectomy. Surg Endosc 2002;16:426-430.

41 Wang X, Li Y, Crook N, Peng B, Niu T. Laparoscopic splenectomy: a surgeon's experience of 302 patients with analysis of postoperative complications. Surg. Endosc 2013;27:3564-3571. 42 Trelles N, Gagner M, Pomp A, Parikh M. Laparoscopic splenectomy for massive splenomegaly: technical aspects of initial ligation of splenic artery and extraction without handassisted technique. J Laparoendosc Adv Surg Tech A 2008;18:391-395.

43 Leandros E, Alexakis N, Albanopoulos K, Dardamanis D, Karagiorga M, Gomatos I, Papadopoulos S, Bacoyiannis C, Bramis J. Hand-assisted laparoscopic surgery with a Pfannenstiel incision in beta-thalassemia patients: initial experience. World $\mathrm{J}$ Surg 2006;30:1216-1220.

44 Maartense S, Bemelman WA, Gerritsen van der Hoop A, Meijer DW, Gouma DJ. Handassisted laparoscopic surgery (HALS): a report of 150 procedures. Surg Endosc 2004;18:397401.

45 Serra F, Roli I, Campanelli M,Cabry F, Baschieri F, Romano F, Gelmini R. Laparoscopic splenectomy in malignancies: is safe and feasible? Minerva Chir 2019;74(5):365-373.

46 Targarona E M, Cerdan G, Gracia E, Rodriguez M, Trias M: Results of laparoscopic splenectomy for treatment of malignant conditions. HPB (Oxford) 2001; 3(4): 251-255. 
47 Vianelli N, Palandri F, Polverelli N, Stasi R, Joelsson J, Johansson E, Ruggeri M, Zaja F, Cantoni S, Catucci AE, Candoni A, Morra E, Björkholm M, Baccarani M, Rodeghiero F. Splenectomy as a curative treatment for immune thrombocytopenia: a retrospective analysis of 233 patients with a minimum follow up of 10 years. Haematologica 2013;98:875-880.

48 Ghanima W, Godeau B, Cines DB, Bussel JB. How I treat immune thrombocytopenia: the choice between splenectomy or a medical therapy as a second-line treatment. Blood 2012;120:960-969.

49 Patel NY, Chilsen AM, Mathiason MA, Kallies KJ, Bottner WA. Outcomes and complications after splenectomy for hematologic disorders. Am J Surg 2012;204:1014-1019.

50 Mikhael J, Northridge K, Lindquist K, Kessler C, Deuson R, Danese M. Short-term and long-term failure of laparoscopic splenectomy in adult immune thrombocytopenic purpura patients: a systematic review. Am J Hematol 2009;84:743-748.

51 Patel VL, Mahévas M, Lee SY, Stasi R, Cunningham-Rundles S, Godeau B, Kanter J, Neufeld E, Taube T, Ramenghi U, Shenoy S, Ward MJ, Mihatov N, Patel VL, Bierling P, Lesser M, Cooper N, Bussel JB. Outcomes 5 years after response to rituximab therapy in children and adults with immune thrombocytopenia. Blood 2012;119:5989-5995.

52 Khellaf M, Charles-Nelson A, Fain O, Terriou L, Viallard JF, Cheze S, Graveleau J, Slama B, Audia S, Ebbo M, Le Guenno G, Cliquennois M, Salles G, Bonmati C, Teillet F, Galicier L, Hot A, Lambotte O, Lefrère F, Sacko S, Kengue DK, Bierling P, Roudot-Thoraval F, Michel M, Godeau B. Safety and efficacy of rituximab in adult immune thrombocytopenia: results from a prospective registry including 248 patients. Blood 2014;124:3228-3236.

53 Ghanima W, Khelif A, Waage A, Michel M, Tjønnfjord GE, Romdhan NB, Kahrs J, Darne B, Holme PA; RITP study group. Rituximab as second-line treatment for adult immune thrombocytopenia (the RITP trial): a multicentre, randomised, double-blind, placebo-controlled trial. Lancet 2015;385:1653-1661.

54 Kuter DJ, Bussel JB, Lyons RM, Pullarkat V, Gernsheimer TB, Senecal FM, Aledort LM, George JN, Kessler CM, Sanz MA, Liebman HA, Slovick FT, de Wolf JT, Bourgeois E, Guthrie TH Jr, Newland A, Wasser JS, Hamburg SI, Grande C, Lefrère F, Lichtin AE, Tarantino MD, Terebelo HR, Viallard JF, Cuevas FJ, Go RS, Henry DH, Redner RL, Rice L, Schipperus MR, Guo DM, Nichol JL. Efficacy of romiplostim in patients with chronic immune thrombocytopenic purpura: a double-blind randomised controlled trial. Lancet 2008;371:395403. 
55 Bussel JB, Provan D, Shamsi T, Cheng G, Psaila B, Kovaleva L, Salama A, Jenkins JM, Roychowdhury D, Mayer B, Stone N, Arning M. Effect of eltrombopag on platelet counts and bleeding during treatment of chronic idiopathic thrombocytopenic purpura: a randomised, double-blind, placebo-controlled trial. Lancet 2009;373:641-648.

56 Tsereteli Z, Smith CD, Branum GD, Galloway JR, Amerson RJ, Chakaraborty H, Hunter JG. Are the favorable outcomes of splenectomy predictable in patients with Idiopathic thrombocytopenic purpura (ITP)? Surg Endosc 2001;15:1386-1389.

57 Shojaiefard A, Mousavi SA, Faghihi SH, Abdollahzade S. Prediction of response to splenectomy in patients with idiopathic thrombocytopenic purpura. World J Surg 2008;32:488493.

58 Fabris F, Tassan T, Ramon R, Carraro G, Randi ML, Luzzatto G, Moschino P, Girolami A. Age as the major predictive factor of long-term response to splenectomy in immune thrombocytopenic purpura. Br J Haematol 2001;112:637-640.

59 Andrès E, Zimmer J, Noel E, Kaltenbach G, Koumarianou A, Maloisel F. Idiopathic thrombocytopenic purpura: a retrospective analysis in 139 patients of the influence of age on the response to corticosteroids, splenectomy and danazol. Drugs Aging 2003;20:841-846.

60 Gonzalez-Porras JR, Escalante F, Pardal E, Sierra M, Garcia-Frade LJ, Redondo S, Arefi M, Aguilar C, Ortega F, de Cabo E, Fisac RM, Sanz O, Esteban C, Alberca I, Sanchez-Barba M, Santos MT, Fernandez A, Gonzalez-Lopez TJ; Grupo de Trombosis y Hemostasia de Castilla y León. Safety and efficacy of splenectomy in over 65-yrs-old patients with immune thrombocytopenia. Eur J Haematol 2013;91:236-241.

61 Rijcken E, Mees ST, Bisping G, Krueger K, Bruewer M, Senninger N, Mennigen R. Laparoscopic splenectomy for medically refractory immune thrombocytopenia (ITP): a retrospective cohort study on longtime response predicting factors based on consensus criteria. Int J Surg 2014;12:1428-1433.

62 Aleem A. Durability and factors associated with long term response after splenectomy for primary immune thrombocytopenia (ITP) and outcome of relapsed or refractory patients. Platelets 2011;22:1-7.

63 Radaelli F, Faccini P, Goldaniga M, Guggiari E, Pozzoli E, Maiolo AT, Ciani A, Pogliani EM. Factors predicting response to splenectomy in adult patients with idiopathic thrombocytopenic purpura. Haematologica 2000;85:1040-1044 
64 Palandri F, Polverelli N, Catani L, Sollazzo D, Romano M, Levorato M, Vianelli N. The choice of second-line therapy in steroid-resistant immune thrombocytopenia: role of platelet kinetics in a single-centre long-term study. Am J Hematol 2014;89:1047-1050.

65 Wang M, Zhang M, Zhou J, Wu Z, Zeng K, Peng B, Niu T. Predictive factors associated with long-term effects of laparoscopic splenectomy for chronic immune thrombocytopenia. Int J Hematol 2013;97:610-616.

66 Montalvo J, Velazquez D, Pantoja JP, Sierra M, López-Karpovitch X, Herrera MF. Laparoscopic splenectomy for primary immune thrombocytopenia: clinical outcome and prognostic factors. J Laparoendosc Adv Surg Tech A 2014;24:466-470.

67 Roca M, Muñiz-Diaz E, Mora J, Romero-Zayas I, Ramón O, Roig I, Pujol-Moix N. The scintigraphic index spleen/liver at 30 minutes predicts the success of splenectomy in persistent and chronic primary immune thrombocytopenia. Am J Hematol 2011;86:909-13.

68 Sarpatwari A, Provan D, Erqou S, Sobnack R, David Tai FW, Newland AC. Autologous 111 In-labelled platelet sequestration studies in patients with primary immune thrombocytopenia (ITP) prior to splenectomy: a report from the United Kingdom ITP Registry. Br J Haematol 2010;151:477-87.

69 Vikse J, Sanna B, Henry BM, Taterra D, Sanna S, Pękala PA, Walocha JA, Tomaszewski KA. The prevalence and morphometry of an accessory spleen: A meta-analysis and systematic review of 22,487 patients. Int J Surg. 2017;45:18-28.

70 Budzynski A, Bobrzyński A, Sacha T, Skotnicki A. Laparoscopic removal of retroperitoneal accessory spleen in patient with relapsing idiopathic thrombocytopenic purpura 30 years after classical splenectomy. Surg Endosc. 2002;16(11):1636.

71 Xu T, Li N, Jin F, Wu K, Ye Z. Predictive Factors of Idiopathic Thrombocytopenic Purpura and Long-term Survival in Chinese Adults Undergoing Laparoscopic Splenectomy. Surg Laparosc Endosc Percutan Tech 2016;26:397-400.

72 Vecchio R, Intagliata E, La Corte F, Marchese S, Cacciola RR, Cacciola E. Late results after splenectomy in adult idiopathic thrombocytopenic purpura. JSLS 2015;19:e2013.00272.

73 Navez J, Hubert C, Gigot JF, Navez B, Lambert C, Jamar F, Danse E, Lannoy V, Jabbour $\mathrm{N}$. Does the site of platelet sequestration predict the response to splenectomy in adult patients with immune thrombocytopenic purpura? Platelets 2015;26:573-576. 
74 Cai Y, Liu X, Peng B. Should we routinely transfuse platelet for immune thrombocytopenia patients with platelet count less than $10 \times 109 / \mathrm{L}$ who underwent laparoscopic splenectomy? World J Surg 2014;38:2267-2272.

$75 \mathrm{Wu}$ Z, Zhou J, Li J, Zhu Y, Peng B. The feasibility of laparoscopic splenectomy for ITP patients without preoperative platelet transfusion. Hepatogastroenterology 2012;59:81-85.

76 Thomsen RW, Schoonen WM, Farkas DK, Riis A, Jacobsen J, Fryzek JP, Sørensen HT. Risk for hospital contact with infection in patients with splenectomy: a population-based cohort study. Ann Intern Med 2009;151:546-555.

77 Vianelli N, Galli M, de Vivo A, Intermesoli T, Giannini B, Mazzucconi MG, Barbui T, Tura S, Baccaranion M; Gruppo Italiano per lo Studio delle Malattie Ematologiche dell'Adulto. Efficacy and safety of splenectomy in immune thrombocytopenic purpura: long-term results of 402 cases. Haematologica 2005;90:72-77.

78 Doobaree IU, Nandigam R, Bennett D, Newland A, Provan D. Thromboembolism in adults with primary immune thrombocytopenia: a systematic literature review and meta-analysis. Eur J Haematol 2016;97:321-330.

79 Thomsen RW, Schoonen WM, Farkas DK, Riis A, Fryzek JP, Sørensen HT. Risk of venous thromboembolism in splenectomized patients compared with the general population and appendectomized patients: a 10-year nationwide cohort study. J Thromb Haemost 2010;8:1413-1416. 